\title{
Arctic sea ice melt onset favored by an atmospheric pressure pattern reminiscent of the North American-Eurasian Arctic pattern
}

\author{
Sean Horvath ${ }^{1,2}$ (D) Julienne Stroeve ${ }^{1,2,3}$ (D) Balaji Rajagopalan ${ }^{2,4}$ (D) Alexandra Jahn $^{5}$ (D)
}

Received: 6 July 2020 / Accepted: 16 April 2021 / Published online: 29 April 2021

(c) The Author(s) 2021

\begin{abstract}
The timing of melt onset in the Arctic plays a key role in the evolution of sea ice throughout Spring, Summer and Autumn. A major catalyst of early melt onset is increased downwelling longwave radiation, associated with increased levels of moisture in the atmosphere. Determining the atmospheric moisture pathways that are tied to increased downwelling longwave radiation and melt onset is therefore of keen interest. We employed Self Organizing Maps (SOM) on the daily sea level pressure for the period 1979-2018 over the Arctic during the melt season (April-July) and identified distinct circulation patterns. Melt onset dates were mapped on to these SOM patterns. The dominant moisture transport to much of the Arctic is enabled by a broad low pressure region stretching over Siberia and a high pressure over northern North America and Greenland. This configuration, which is reminiscent of the North American-Eurasian Arctic dipole pattern, funnels moisture from lower latitudes and through the Bering and Chukchi Seas. Other leading patterns are variations of this which transport moisture from North America and the Atlantic to the Central Arctic and Canadian Arctic Archipelago. Our analysis further indicates that most of the early and late melt onset timings in the Arctic are strongly related to the strong and weak emergence of these preferred circulation patterns, respectively.
\end{abstract}

Keywords Arctic sea ice $\cdot$ Melt onset $\cdot$ Climate variability $\cdot$ Self organizing maps (SOM) - Atmospheric circulation · Atmospheric moisture transport

\section{Introduction}

Spring and summer in the Arctic are periods of great change and uncertainty. Warm weather and an increase in atmospheric moisture content produce changes to the snow and sea ice cover, drastically altering the energy budget of the Arctic, which in turn affects planetary atmospheric and oceanic

Sean Horvath

sean.horvath@colorado.edu

1 National Snow and Ice Data Center, University of Colorado, Boulder, USA

2 Cooperative Institute for Research in Environmental Sciences at University of Colorado, Boulder, USA

3 Earth Sciences Department, University College of London, London, UK

4 Department of Civil, Environmental, and Architectural Engineering, University of Colorado, Boulder, USA

5 Department of Atmospheric and Oceanic Sciences and Institute of Arctic and Alpine Research, University of Colorado, Boulder, USA circulation. Yearly sea ice cover has an average decrease of $4 \%$ per decade (Cavalieri and Parkinson 2012) since the beginning of the satellite era, with the most pronounced decline occurring at the end of the melt season in September (Onarheim et al. 2018; Stroeve and Notz 2018). This decrease, particularly during summer months (June, July, August, and September) has led to an extension of the Arctic Ocean open water season by about a week each decade (Stroeve et al. 2014). The corresponding increase in Arctic accessibility is of keen interest for military activity, resource extraction, shipping, tourism, and scientific research (Cronk 2019; Eguíluz et al. 2016; Ellis and Brigham 2009; Garamone 2019; Hansen et al. 2016). Open water shipping routes along the Northern Sea Route, over the North Pole, and through the Northwest Passage are expected to become navigable by the mid-twenty-first century, impacting environmental, strategic, economic, and governance for the Arctic region (Smith and Stephenson 2013). This increase in activity in the Arctic Ocean requires a better understanding of the mechanisms driving sea ice loss and a need to determine sources of predictability on synoptic and seasonal 
scales. The present study provides insights into the synoptic atmospheric patterns that are associated with southerly moisture advection in relation to the timing of melt onset.

Conditions during the transition from winter to spring play an important role in summer sea ice variability (Perovich and Polashenski 2012). The first appearance of liquid meltwater in the snow pack, termed melt onset, is a key attribute that sets the stage for the melt season. The presence of liquid water reduces the high albedo of snow, causing a rapid increase in heat flux to the ice and snow pack,

Table 1 Statistics for the regionally averaged timing of melt onset in the Arctic using the melt onset algorithm of Markus et al. (2009)

\begin{tabular}{llll}
\hline Sea & $\begin{array}{l}\text { Trend (days per } \\
\text { decade) }\end{array}$ & $\begin{array}{l}\text { Standard error } \\
\text { (days) }\end{array}$ & $\begin{array}{l}\text { Standard } \\
\text { deviation } \\
\text { (days) }\end{array}$ \\
\hline Kara & -5.0 & 0.12 & 10.11 \\
Laptev & -1.9 & 0.10 & 7.38 \\
East Siberian & -0.7 & 0.08 & 5.51 \\
Chukchi & -1.4 & 0.10 & 7.36 \\
Beaufort & -2.2 & 0.09 & 6.67 \\
Canadian Arctic & -1.3 & 0.07 & 5.33 \\
$\quad$ Archipelago & & & 5.22 \\
Central Arctic & -1.4 & 0.07 & \\
\hline
\end{tabular}

Trend and standard error are determined by an ordinary least squares linear regression over the years 1979-2018 promoting further melt. Earlier melt onset leads to early open ocean conditions which greatly absorb heat through solar radiation (Perovich et al. 2007), leading to delayed freeze up (Stroeve et al. 2014) and therefore longer open water conditions. As the snow melts, melt water accumulates in melt ponds, the timing of which plays a role in how much ice is left over at the end of summer (e.g. Schröder et al. 2014).

As with the trends in declining sea ice cover trends in the timing of melt onset have been reported in previous studies (e.g. Markus et al. 2009; Stroeve et al. 2014; Bliss and Anderson 2014; Stroeve and Notz 2018), with all studies demonstrating earlier occurrence in recent years (e.g. Table 1, Fig. 1). These negative trends are expected to continue to do so in the future (Smith and Jahn 2019). The strongest trend and greatest variability occurs in the Kara Sea while the weakest trend is found in the East Siberian Sea.

Identifying the drivers of melt onset may also help improve the predictability of the remainder of the melt season. In particular, Schröder et al. (2014) found a strong correlation $(-0.80)$ between spring melt pond fraction and September sea ice extent. The lower albedo of melt ponds compared to snow covered or bare ice result in greater solar absorption and more melting. Early formation of melt ponds is therefore a powerful indicator of strong summer sea ice retreat. The melt pond fraction in May in particular has been

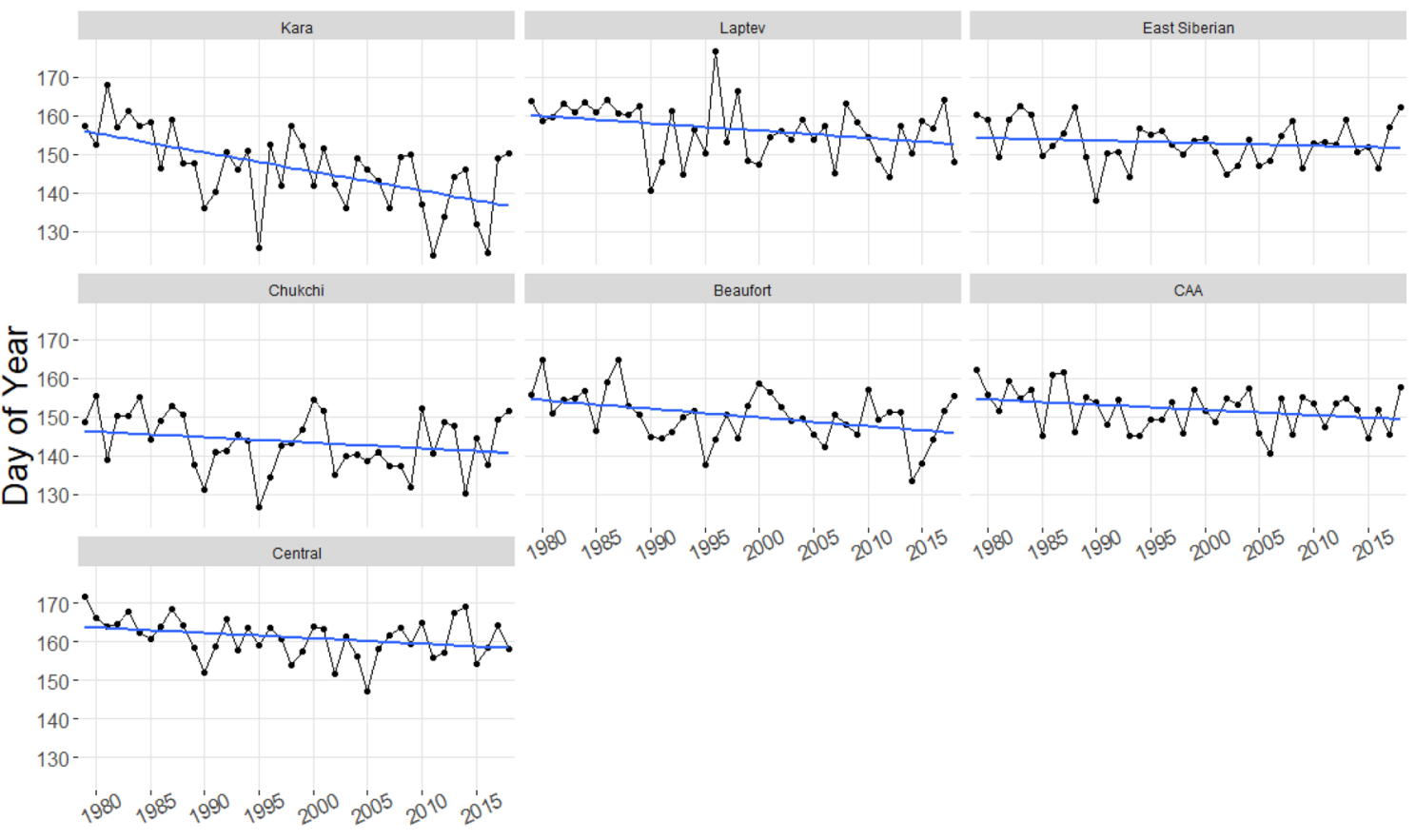

Year

Fig. 1 Trends in the timing of melt onset in the Arctic by sea. All regions show a trend towards earlier melt onset in recent years using the melt onset algorithm of Markus et al. (2009). All regions except the East Siberian and Chukchi seas show statistically significant trends at the $90 \%$ confidence level 
found to have a strong impact on the summer sea ice state (Schröder et al. 2014). Additionally, anomalous radiative forcing in June has been associated with September sea ice extent anomalies (Huang et al. 2019). The radiative anomalies are likely partially due to the June North Atlantic Oscillation (NAO) index which, in its negative phase, results in anomalous high pressure over the pole and has been identified as a possible forcing mechanism for September sea ice melt (Ding et al. 2019; Li et al. 2015; Wernli \& Papritz, 2018).

While the importance of melt onset is clear, the mechanisms driving it are still being explored. Mortin et al. (2016) found that melt onset is triggered by positive anomalies of water vapor, clouds, and air temperature that increase the downwelling longwave radiation to the surface. These moisture anomalies are due to atmospheric transport from remote areas rather than moisture fluxes from the Arctic surface due to the high insulation properties of ice and snow (Boisvert et al. 2013). Atmospheric moisture transport, or moisture intrusions, have been linked to the formation of supercooled liquid water clouds and therefore the enhancement of net surface energy fluxes via increased downwelling longwave radiation (Ali and Pithan 2020; Persson et al. 2017). Tracking these moisture sources is of keen interest and has been explored with regard to other Arctic events (Drumond et al. 2016; Stohl 2006; Vázquez et al. 2016).

In the following, we provide insights into which atmospheric circulation patterns, and the associated southerly moisture advection, lead to melt onset and how the timing of these patterns affects the occurrence of early melt onset. This is achieved through the use of a Self-Organizing Map (SOM) analysis on daily sea level pressure (SLP), compared to daily instances of melt onset across the Arctic derived from passive microwave data.

\section{Data}

The dates of melt onset are obtained from the microwave radiometers Scanning Multichannel Microwave Radiometer, Special Sensor Microwave/Imager, and Special Sensor Microwave Imager and Sounder (Markus et al. 2009; Stroeve et al. 2014). Microwave emissions are directly related to the melt signature of ice and snow (Markus et al. 2009), as meltwater forms in the snowpack its dielectric properties change and its emissivity increases. Melt onset can therefore be determined by the increase in liquid water at depth within the snowpack, which is detected based on the temporal variability of brightness temperatures at $19 \mathrm{GHz}$ and $37 \mathrm{GHz}$ in different combinations (Markus et al. 2009). Two melt onset products exist in this data set, early melt onset (EMO), the first date melt water is detected, and continuous melt onset (MO), which persists until freeze-up. This study uses EMO (termed melt onset from here on) as it has been found to be more closely associated with synoptic atmospheric processes (Mortin et al. 2016). The melt data is provided at a $25 \mathrm{~km}$ by $25 \mathrm{~km}$ spatial resolution and is re-projected from NSIDC's polar stereographic projection to the Equal-Area Scalable Earth Grid 2.0 (EASE-Grid 2.0) (Brodzik et al. 2012, 2014) for the period 1979-2018. The Arctic domain is divided into 7 seas: the Beaufort, Chukchi, East Siberian, Laptev, Kara, Central Arctic, and Canadian Arctic Archipelago (CAA). While the SOM analysis is done on the entire Arctic domain north of $60^{\circ} \mathrm{N}$, the effect on melt onset is only identified in the seas depicted in Fig. 2.

Daily sea level pressure (SLP, in units of Pa), surface air temperature (air temperature at $925 \mathrm{hpa}$, SAT, in units of ${ }^{\circ} \mathrm{C}$ ), downwelling longwave radiation (LWDN, in units of $\mathrm{W} \mathrm{m}^{-2}$ ), and integrated vapor transport (IVT, in units of $\mathrm{kg} \mathrm{m}^{-1} \mathrm{~s}^{-1}$ ) are from ECMWF Reanalysis 5th Generation (ERA5; Copernicus Climate Change Service (C3S), 2017). ERA5 was produced using 4D-Var data assimilation in CY41R2 of ECMWF's Integrated Forecast System (IFS), with 137 hybrid sigma/pressure (model) levels in the vertical, with the top level at $0.01 \mathrm{hPa}$. Values are spatially aggregated to a spatial resolution of $0.5^{\circ}$ latitude by $0.5^{\circ}$ longitude. Studies have shown ERA5 to perform favorably in the Arctic (though evaluations have been limited in time and space as they are compared to in-situ observations) in terms of surface meteorology and radiation (Babar et al.

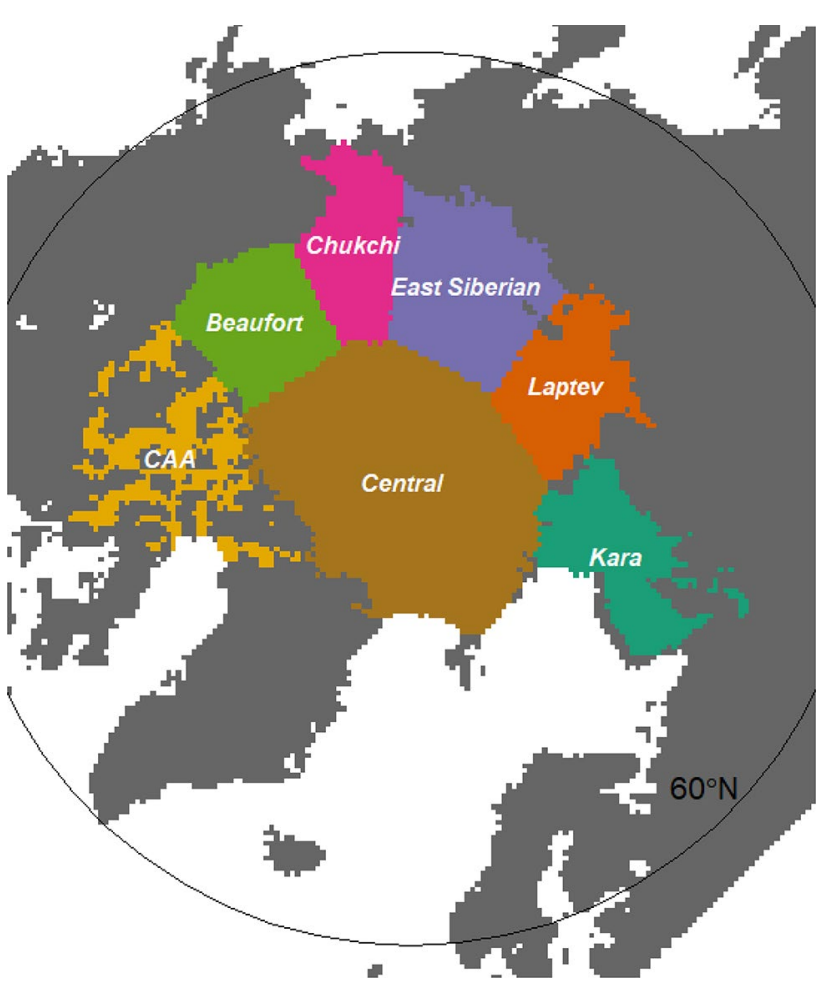

Fig. 2 Subregions of the Arctic Ocean analyzed in this study 
2019; Graham et al. 2019), particularly in spring and summer (Graham et al. 2019). ERA5 does produce biased estimates of these variables, so daily anomalies are used in this study. The atmospheric data was subsetted to only include locations with a latitude $>60 \mathrm{~N}$ and were re-projected to the Equal-Area Scalable Earth Grids, or EASE2.0, projection (Brodzik and Knowles 2002; Brodzik et al. 2012, 2014). Re-projecting to an equal area grid is important for equal weighting of the grid cells in the SOM algorithm. For all atmospheric data, daily mean values were used, covering the possible dates of melt onset (day of year 75-210) for the years 1979-2018. Anomalous SLP values were found by subtracting the daily domain-averaged SLP from all grid points following the methodology used by Cassano et al. (2007). This preserves pressure gradients which are connected to atmospheric circulation. Areas with elevations greater than $500 \mathrm{~m}$ (over Greenland) were masked from SLP fields used in the SOM analysis due to errors associated with reducing surface pressure to SLP for high-elevation locations (Mohr 2004; Wallace and Hobbs 2006). Anomalies for other atmospheric variables are found grid point by grid point by removing the daily mean climatology from 1980 to 2010 .

\section{Methodology}

A SOM analysis is applied to the daily SLP fields to determine circulation patterns and moisture advection in relation to melt onset dates. The dates used for SLP range from day of year 75 through 210 for the years 1979-2018. SOMs are unsupervised neural networks based on competitive learning that can nonlinearly map high-dimensional data into 2-dimensions (Kohonen 1990; Vesanto and Alhoniemi 2000). Similar to cluster analysis, SOMs reduce large datasets into smaller representative samples based on the learning algorithm. This technique has been used in numerous Arctic studies (Cassano et al. 2016; Higgins and Cassano 2009; Horton et al. 2015; Johnson et al. 2008; Skific et al. 2009; Skific and Francis 2012; Yu et al. 2018) as well as specifically in relation to Arctic moisture transport (Mioduszewski et al. 2016).

The SOM network is fit to the dataset by calculating the Euclidean distance between an observation and each node. Through competitive learning, a single node is activated at each iteration in which the dataset is presented to the neural network. The node with the smallest Euclidean distance is chosen as the "winning" node (Best Matching Unit, BMU), after which its weight vector, along with the neighboring nodes within a given radius, are updated to more similarly reflect the given data point. The algorithm is described in the supplemental section.
For this study we implemented SOM with the 'kohonen' package (Wehrens and Buydens 2007; Wehrens and Kruisselbrink 2018) in the $\mathrm{R}$ programming language ( $\mathrm{R}$ Core Team 2019). We set $n=10,000$, the grid size to 5 columns by 4 rows, and used default settings for the remaining parameters. The number of nodes is chosen by the user a priori and is a trade-off between missing the full spectrum of possible patterns and forcing observations into classifications that are a poor fit (too few nodes) and an overwhelming amount of data with too little difference between samples (too many nodes). A range of node configurations were empirically tested for this study and 20 was determined to be a fitting balance between trade-offs. Decreasing the SOM nodes by even 1 dimension (i.e., 4 columns and 4 rows) led to results that miss important pressure patterns (namely nodes 3 and 13, discussed further in Sect. 4.2). The "master" SOM of SLP depicts the range of pressure patterns during the melt season and each day is assigned to a node, so any field from the same dates can be composited for each node. This is applied to the variables described in Sect. 2.

Yearly melt onset data is redefined as a daily dataset in which melt onset at each location either occurred or did not, and a total count of melt onset per location is found for each node. Valid dates range from day of year 75 through 210 for years 1979-2018. Nodes with high and low counts of melt onset are selected for further analysis.

For the Beaufort, Chukchi, East Siberian, Laptev, Kara, CAA, and the Central Arctic seas, the top four nodes that contribute most to melt onset are identified and the frequency with which these circulation patterns appear is determined. Finally, regional mean melt onset dates per year are used to determine early and late melt onset years. The frequency with which the top four nodes appear early in the melt season are found and compared for early and late years. Statistical significance is determined by generating binomial distributions and testing the hypothesis that the difference between the early and late melt onset years is zero following the method of Cassano et al. (2007). The test statistic, $Z_{0}$, to test the difference in frequency assumes two binomial processes and is given by:

$$
Z_{0}=\frac{\left(p_{2}-p_{1}\right)}{\sqrt{\frac{p_{1}\left(1-p_{1}\right)}{n_{1}}+\frac{p_{2}\left(1-p_{2}\right)}{n_{2}}}},
$$

where $p_{1}$ and $p_{2}$ are the frequency of occurrence for early and late years, respectively, $p_{1}\left(1-p_{1}\right) / n_{1}$ and $p_{2}\left(1-p_{2}\right) / n_{2}$ are estimators of the node frequency variances, and $n_{1}$ and $n_{2}$ are the number of days in each time period. 


\section{Results}

\subsection{SOM analysis of sea level pressure}

The master SOM arranges SLP fields into a range of patterns that occur during the melt season (Fig. 3) with the strongest anomalies occurring on the outer edges of the SOM map. Nodes in the upper left corner show low pressure over the North Atlantic and high pressure over Eurasia and/or the central Arctic, reminiscent of the North Atlantic Oscillation (NAO). The lower right corner is characterized by a low pressure system over parts of the North Atlantic, Europe and into Eurasia along with a high pressure system over North America. This pattern resembles a North American-Eurasian Arctic dipole anomaly and promotes atmospheric flow from the North Pacific across the central Arctic to the Atlantic (Overland and Wang 2005). The top right (bottom left) nodes show a high (low) pressure system over the central Arctic with low (high) pressure at lower latitudes. The sharp contrasts between corners is a typical feature of SOM, which helps to understand the extremes better. Nodes in the center of the SOM map are a mixture of the patterns found on the map edges, but are characterized by generally weaker anomalies. However, small differences in location and depth of pressure fields have been shown to be important factors in sea ice variability (Serreze et al. 2016).

\subsection{Relationships between SLP, integrated vapor transport and melt onset}

The number of times melt onset occurs at each grid cell is summed for each node to examine how different regions in the Arctic are influenced by each atmospheric pressure pattern (Fig. 4). There are clear differences in the influence of the identified atmospheric circulation patterns on the occurrence of melt onset. To examine further, we obtain regional averages for the 7 Arctic regions shown in Fig. 2. While the delineation of these regions can be viewed as arbitrary or artificial, they provide a useful means of conducting a regional analysis of the Arctic Ocean.

By identifying the leading nodes that contribute to melt onset for each region (Table 2), we find that nodes 2, 3, 9, $10,13,15,17,18$, and 19 fall within the leading 4 nodes (the number of nodes used here does not significantly impact
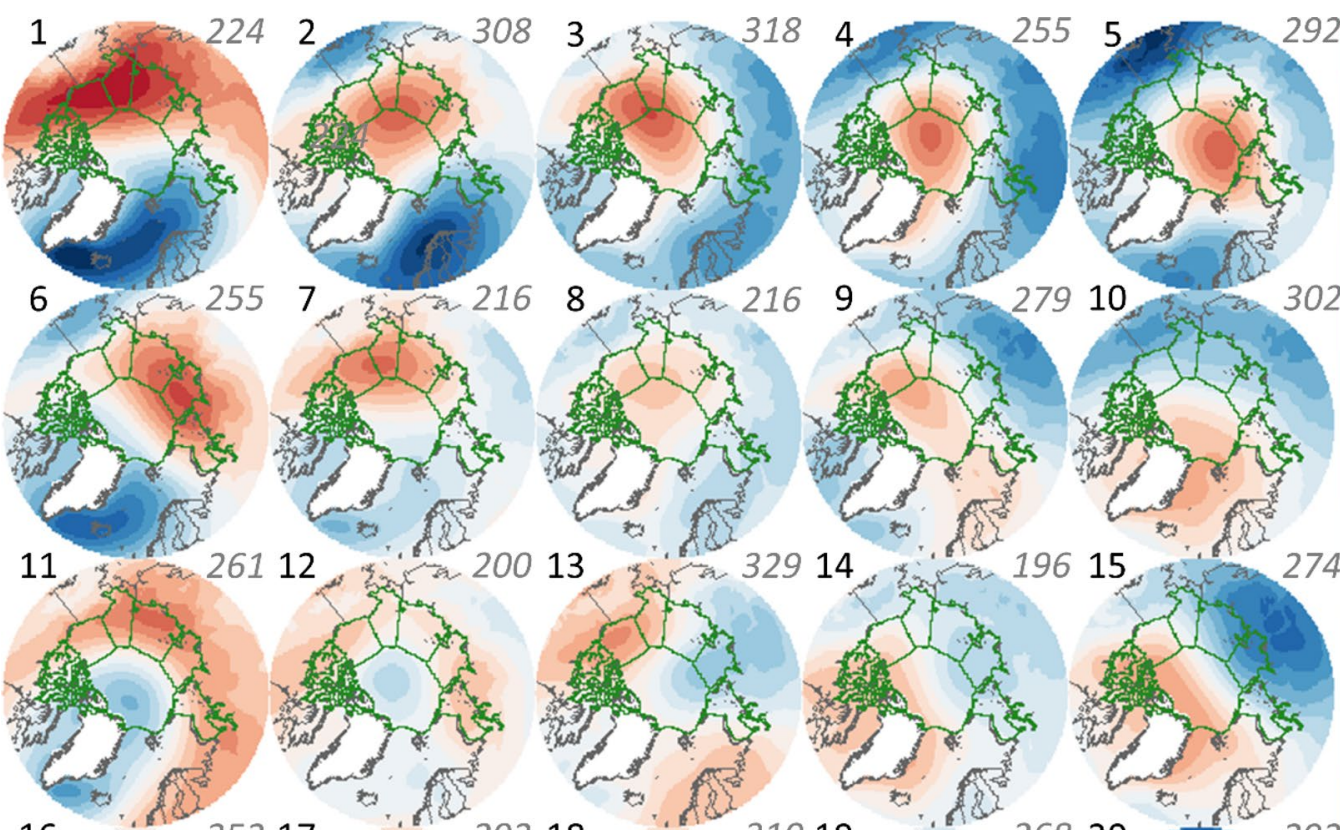

15

10
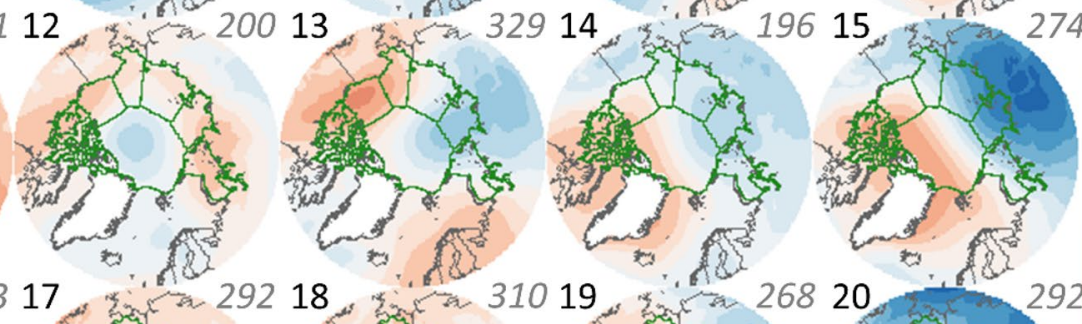

0
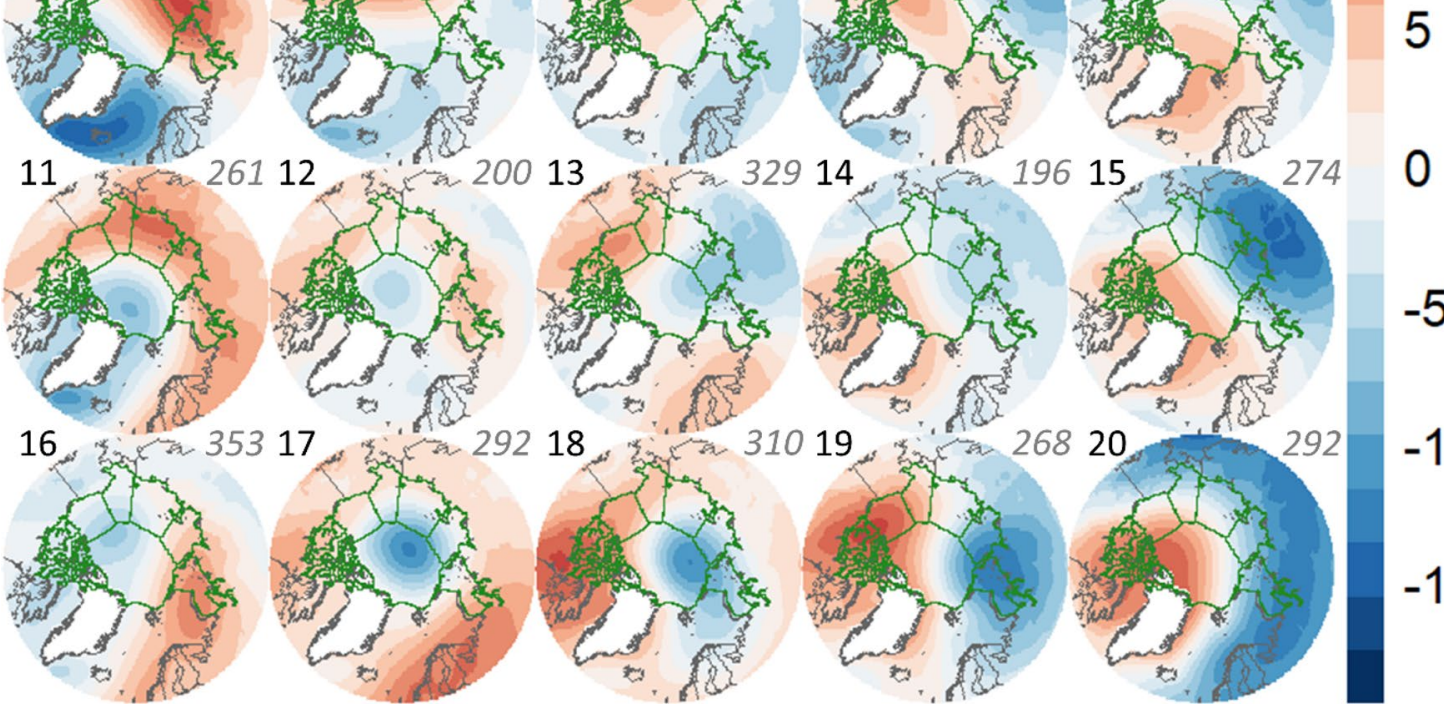

Fig. 3 Master SOM of daily SLP anomaly fields during the melt season (1979-2018). Units are in $\mathrm{hPa}$ as these are composites of the daily SLP. Numbers in black are the node number, numbers in grey italics are the total number of occurrences of each pattern (out of 5440 total days used in training), and green lines delineate the 7 Arctic regions shown in Fig. 2 
Fig. 4 Count of melt onset occurrence mapped to the master SOM. Units are the number of times melt onset occurred at each grid cell for a given node (max is 40 since melt onset can only occur once per year at any grid cell, and we are using 40 years of data). Numbers in black are the node number and green lines delineate the 7 Arctic regions shown in Fig. 2

Table 2 Percentage of times melt onset occurs for each sea

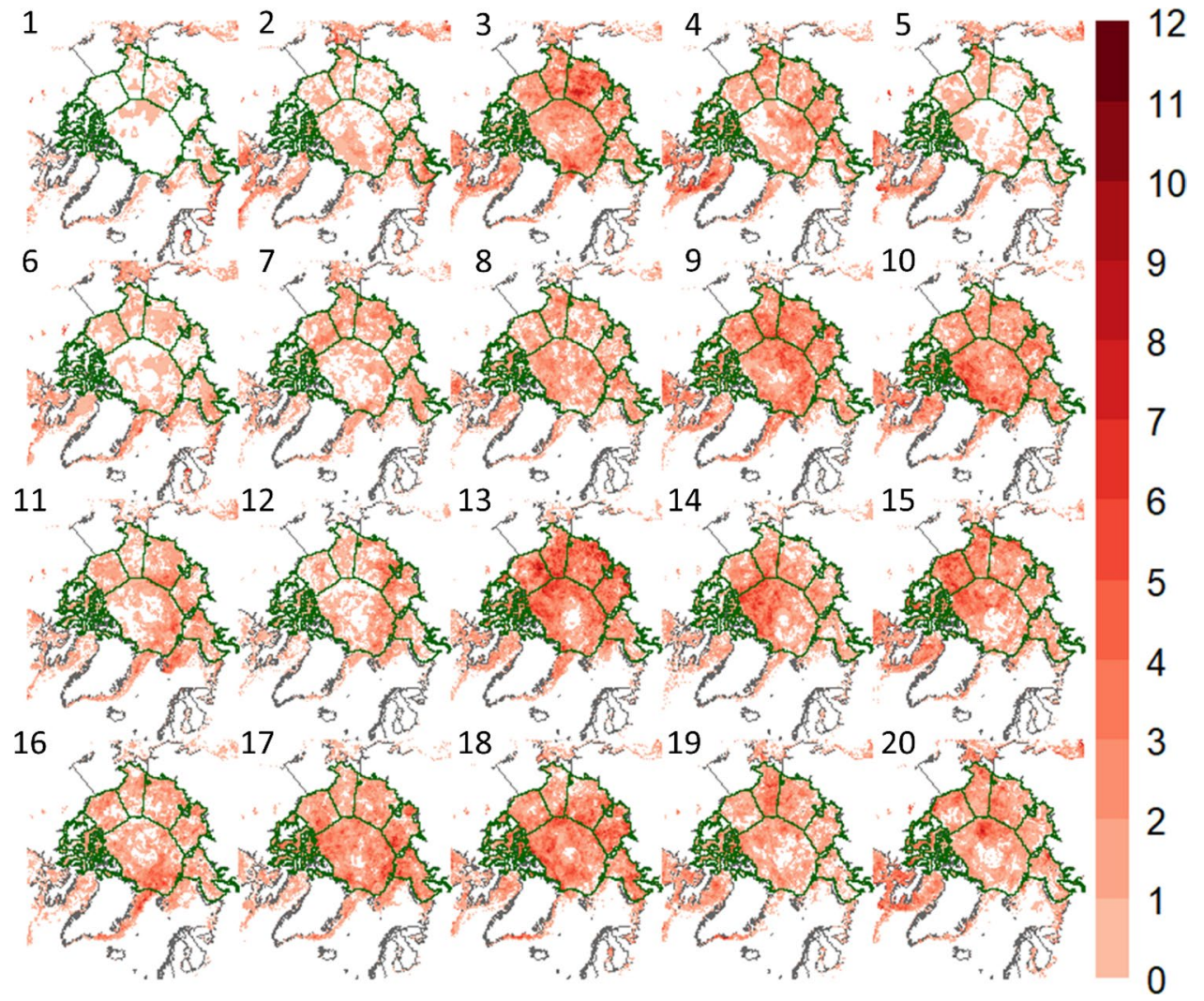

\begin{tabular}{lllll}
\hline Sea & 1st & 2nd & 3rd & 4th \\
\hline Kara & Node 17: $9.13 \%$ & Node 18: 8.55\% & Node 10: 6.18\% & Node 2: 6.06\% \\
Laptev & Node 13: 11.20\% & Node 18: 10.10\% & Node 17: 7.88\% & Node 9: 7.62\% \\
East Siberian & Node 13: 10.90\% & Node 3: 9.93\% & Node 9: 8.40\% & Node 18: 6.84\% \\
Chukchi & Node 13: 10.30\% & Node 15: 8.47\% & Node 19: 7.80\% & Node 9: 7.75\% \\
Beaufort & Node 15: $11.80 \%$ & Node 13: 9.69\% & Node 18: 7.08\% & Node 9: 6.85\% \\
Central & Node 13: $9.09 \%$ & Node 18: 8.74\% & Node 10: 8.37\% & Node 17: 7.86\% \\
CAA & Node 10: $9.13 \%$ & Node 13: 8.33\% & Node 18: 7.81\% & Node 15: 7.54\% \\
\hline
\end{tabular}

The top four nodes are shown results). Nodes 13,15, and 18, all of which are characterized by a high pressure system over North America accompanied by a lower pressure over Siberia or Siberian seas (Fig. 3), appear in at least 3 regions as the top first or second leading node. Nodes 17 ad 10 are the leading nodes in the Kara Sea and CAA, respectively, and are in the top 4 nodes for 2 additional regions. Node 17 is characterized by a low pressure system over the central Arctic surrounded by higher pressure at lower latitudes. Node 10 depicts an Atlantic-Pacific dipole pattern that promotes southerly advection from North America into and across the central Arctic. Node 9, characterized by a high pressure system over the Beaufort Sea and central Arctic accompanied by low pressure over Siberia and southern Greenland, is the third or fourth leading node in four of the seven regions. Nodes 3,19, and 2 appear only once as the second leading node for the East Siberian Sea, the third leading node for the Chukchi Sea, and the fourth leading node for the Kara Sea, respectively. To understand the atmospheric conditions that lead to melt onset under these different SLP patterns, anomalous composite maps of integrated vapor transport, air temperature, and downwelling longwave radiation are assessed using all days associated with select nodes (only nodes 13, 15, 18, 17, 10, and 3 are shown as these are in the top two leading nodes). Regional mean values for IVT, SAT, and LWDN in each node are summarized in Table 3.

The persistence of atmospheric patterns, not merely their presence, has been found to be an important factor in the development of the melt season (Kapsch et al. 2019). When an atmospheric pattern that is conducive to warm, 
Table 3 Anomalous values for IVT $\left[\mathrm{kg} \mathrm{m}^{-1} \mathrm{~s}^{-1}\right]$, SAT $\left[{ }^{\circ} \mathrm{C}\right]$, and LWDN $\left[\mathrm{W} \mathrm{m}^{-2}\right]$

\begin{tabular}{rlrrrrrrr}
\hline Node & Variable & Kara & Laptev & East Siberian & Chukchi & Beaufort & CAA & Central \\
\hline 3 & IVT & 36.94 & 40.44 & 40.43 & 21.75 & 29.98 & 22.28 & 29.62 \\
& SAT & 0.27 & 1.37 & 2.69 & 2.16 & 0.08 & -0.84 & 1.45 \\
& LWDN & 2.47 & 5.97 & 8.36 & 2.24 & -0.74 & -1.01 & 2.77 \\
10 & IVT & 26.15 & 29.62 & 24.50 & 20.07 & 33.55 & 32.40 & 29.07 \\
& SAT & 0.00 & -0.94 & -1.08 & -0.57 & 1.19 & 1.94 & 0.85 \\
& LWDN & 1.59 & 2.12 & 0.18 & 2.76 & 2.33 & 3.84 & 0.64 \\
13 & IVT & 28.80 & 26.07 & 35.10 & 23.16 & 19.1 & 14.61 & 25.64 \\
& SAT & -1.59 & 0.50 & 1.91 & 1.63 & 0.96 & 0.04 & -0.39 \\
& LWDN & -2.75 & 3.58 & 4.38 & 1.77 & 2.34 & 2.12 & 0.47 \\
15 & IVT & 35.53 & 27.64 & 35.95 & 39.20 & 28.27 & 17.71 & 32.43 \\
& SAT & -1.49 & -1.30 & 0.57 & 2.30 & 3.27 & 1.46 & 0.61 \\
& LWDN & -2.94 & 1.68 & 4.21 & 9.65 & 7.25 & 1.90 & 1.39 \\
17 & IVT & 51.25 & 62.54 & 65.00 & 50.81 & 54.10 & 34.62 & 39.94 \\
& SAT & 0.29 & -0.27 & -1.18 & -1.65 & -0.77 & 0.25 & -1.30 \\
& LWDN & 4.95 & 1.75 & -1.61 & -2.16 & 1.86 & 1.20 & -2.07 \\
18 & IVT & 40.18 & 47.77 & 38.71 & 23.40 & 20.46 & 17.70 & 36.27 \\
& SAT & 0.90 & 0.46 & 0.34 & 0.18 & 0.97 & 1.54 & -0.93 \\
& LWDN & 7.48 & 2.96 & 3.11 & 2.44 & 4.12 & 4.25 & 2.16 \\
\hline
\end{tabular}

Values are averaged over each region for nodes $3,10,13,15,17$, and 18 moist air intrusions persists for several days, it can precondition the snow pack which aides in the eventual continuous melt onset. Here we find that both LWDN and SATs often increase in the 2-3 days leading up to melt onset with each atmospheric pattern identified (Figures S1 \& S2). However, if we compare the occurrence of melt onset when patterns persist for at least 3 consecutive days to when patterns last less than 3 consecutive days (Figures S3 \& S4), the same or similar nodes emerge as frequent melt nodes (nodes 13, 14, 15 , and 18 in the case of persistence and nodes $9,10,14,17$ in the case of non-persistence). This suggests that the persistence of nodes 13,15 , and 18 can help explain why these nodes stand out as leading to melt onset, but that the general circulation pattern they exhibit (high pressure over the central Arctic/North America and low pressure over Eurasia, similar to nodes 9, 10, and 17) can also induce melt onset even when they are not relatively persistent.

For node 13, the elongated low-pressure system spanning from terrestrial Siberia into the Laptev Sea (Fig. 3, node 13) promotes atmospheric vapor transport from northern Eurasia to southern Siberia before turning north and crossing the Laptev $\left(+26.07 \mathrm{~kg} \mathrm{~m}^{-1} \mathrm{~s}^{-1}\right)$ and Beaufort $\left(+19.0 \mathrm{~kg} \mathrm{~m}^{-1} \mathrm{~s}^{-1}\right)$ Seas (Fig. 5b). This moisture pathway merges with another pathway from the north Pacific as they cross the East Siberian $\left(+35.1 \mathrm{~kg} \mathrm{~m}^{-1} \mathrm{~s}^{-1}\right)$ and Chukchi $\left(+23.16 \mathrm{~kg} \mathrm{~m}^{-1} \mathrm{~s}^{-1}\right)$ Seas leading to more frequent melt onset over the Laptev (11.2\%), Chukchi (10.3\%), Beaufort (9.7\%), and East Siberian (10.9\%) Seas (Fig. 5a). Anomalously higher air temperature (Laptev: $+0.5{ }^{\circ} \mathrm{C}$; Chukchi: $+1.63{ }^{\circ} \mathrm{C}$; Beaufort: $+0.96{ }^{\circ} \mathrm{C}$; East
Siberian: $+1.19^{\circ} \mathrm{C}$ ) and downwelling longwave radiation (Laptev: $+3.58 \mathrm{~W} \mathrm{~m}^{-2}$; Chukchi: $+1.77 \mathrm{~W} \mathrm{~m}^{-2}$; Beaufort: $+2.34 \mathrm{~W} \mathrm{~m}^{-2}$; East Siberian: $+4.38 \mathrm{~W} \mathrm{~m}^{-2}$ ) occur in these same areas (Fig. 5c, d).

Days assigned to node 15 are tied to the greatest melt onset rate in the Beaufort Sea $(11.8 \%)$, followed by the Chukchi (8.5\%), CAA (7.5\%), and East Siberian (6.6\%) Seas (Fig. 6a). This coincides with anomalously strong southerly moisture advection (Fig. 6b). Anomalous water vapor transport primarily comes from the Pacific and eastern Asia merging with transport from North America over the Beaufort $\left(+28.3 \mathrm{~kg} \mathrm{~m}^{-1} \mathrm{~s}^{-1}\right)$, East Siberian $\left(+36.0 \mathrm{~kg} \mathrm{~m}^{-1} \mathrm{~s}^{-1}\right)$ and Chukchi $\left(+39.2 \mathrm{~kg} \mathrm{~m}^{-1} \mathrm{~s}^{-1}\right)$ Seas before traveling to the central Arctic $\left(+32.4 \mathrm{~kg} \mathrm{~m}^{-1} \mathrm{~s}^{-1}\right)$ (Fig. 6b). This is consistent with the anomalously low pressure over northern Siberia (Fig. 3, node 15). Melt onset in the CAA is additionally influenced by southerly moisture advection from the North Atlantic that pivots around the southern tip of Greenland before moving north. Higher air temperature anomalies are present across much of the North American sector of the Arctic Ocean (Beaufort: $+3.27{ }^{\circ} \mathrm{C}$; CAA: $+1.46{ }^{\circ} \mathrm{C}$; Chukchi: $+2.3{ }^{\circ} \mathrm{C}$ ). Lower air temperature anomalies are present over the Kara $\left(-1.49{ }^{\circ} \mathrm{C}\right)$, and Laptev $\left(-1.3{ }^{\circ} \mathrm{C}\right)$ Seas (Fig. 6c). Downwelling longwave radiation is strongest over the Chukchi $\left(+9.65 \mathrm{~W} \mathrm{~m}^{-2}\right)$, Beaufort $\left(+7.25 \mathrm{~W} \mathrm{~m}^{-2}\right)$, and East Siberian $\left(+4.21 \mathrm{~W} \mathrm{~m}^{-2}\right)$ Seas, but there is also a small positive anomaly $\left(+1.68 \mathrm{~W} \mathrm{~m}^{-2}\right)$ over the Laptev Sea (Fig. 6d) despite low air temperature $\left(-1.30{ }^{\circ} \mathrm{C}\right)$; this is likely due to the low pressure system over the Laptev Sea, promoting 
a)

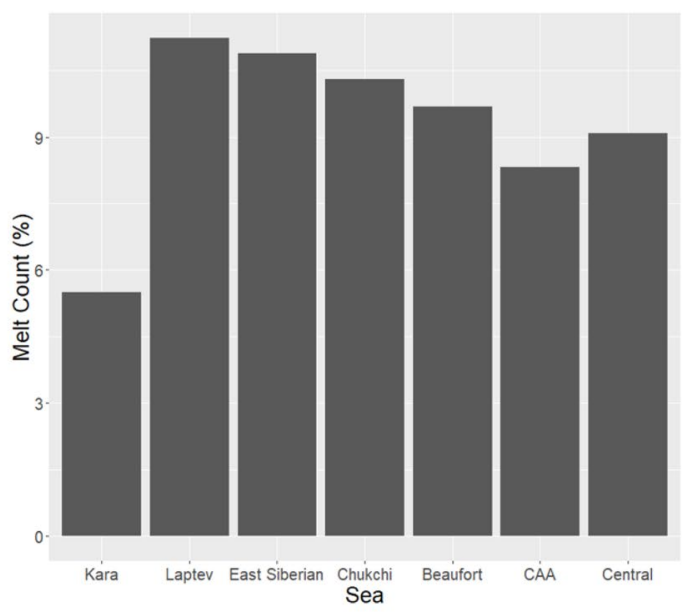

c)

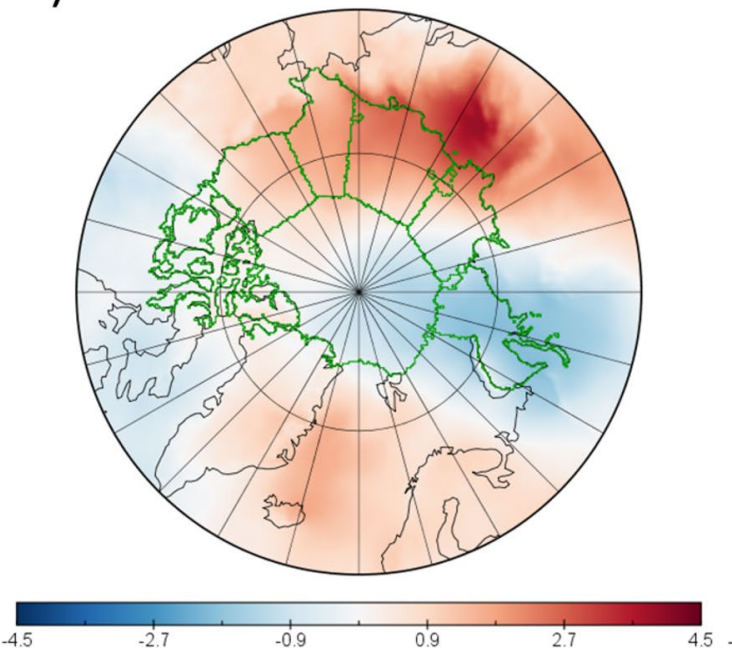

Fig. 5 Composites of node 13 showing a percentage melt onset that occurs on days assigned to this node, $\mathbf{b}$ integrated vapor transport (using anomalous vector components, $\mathrm{kg} \mathrm{m}^{-1} \mathrm{~s}^{-1}$ ), $\mathbf{c}$ anomalous air

low level cloud formation that can increase downwelling longwave radiation.

Days assigned to node 18 exhibit high rates of melt onset in the Laptev (10.1\%) and Kara (8.6\%) Seas and the Central Arctic (8.7\%), concurrent with moisture advection over these regions (Laptev: $+47.77 \mathrm{~kg} \mathrm{~m}^{-1} \mathrm{~s}^{-1}$; Kara: + $40.17 \mathrm{~kg} \mathrm{~m}^{-1} \mathrm{~s}^{-1}$; Central: $+36.27 \mathrm{~kg} \mathrm{~m}^{-1} \mathrm{~s}^{-1}$ ) originating from Eurasia (Fig. 7b). The low-pressure system over the Eurasian sector of the central Arctic (Fig. 3, node 18) promotes this moisture transport from Europe and Asia entering the Arctic over the Laptev and East Siberian seas before reaching the central Arctic. Air temperature anomalies are low throughout the northern Arctic ocean (Central: $-0.93{ }^{\circ} \mathrm{C}$ ), but more southerly latitudes show high anomalies, especially along the Siberian coastline while high b)

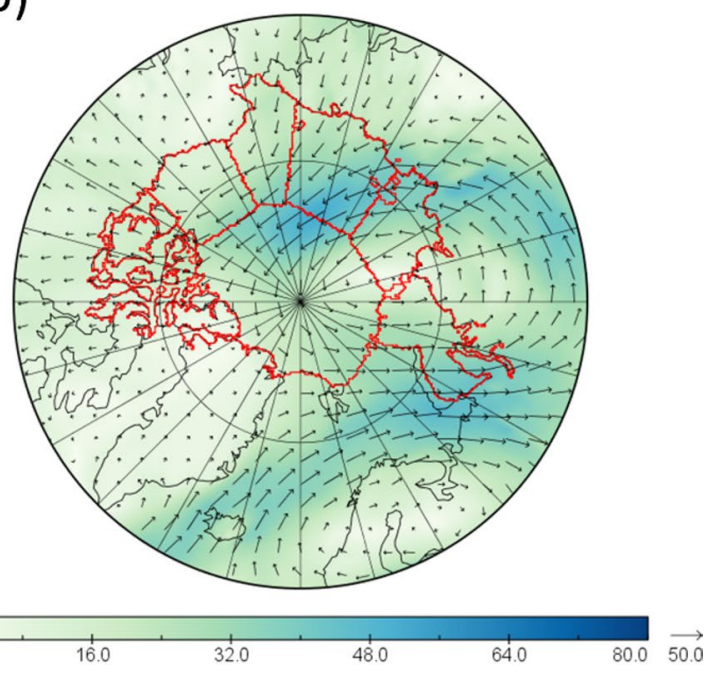

d)

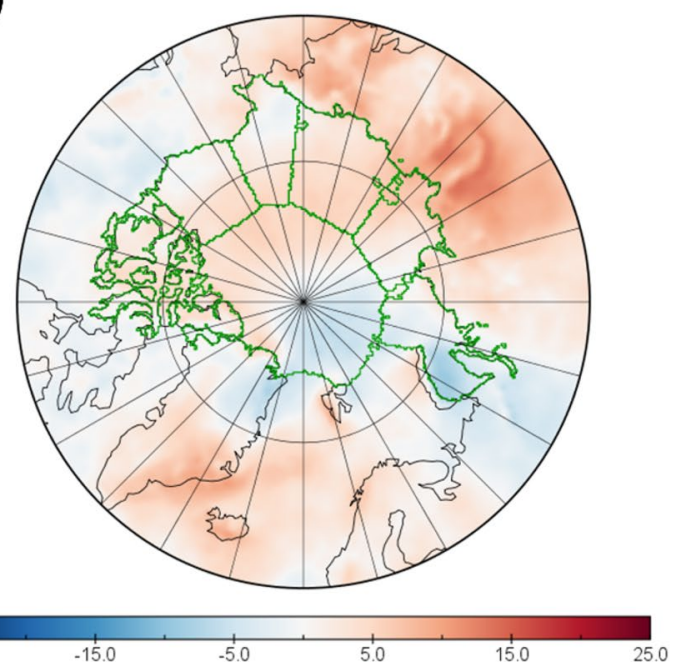

temperature at $925 \mathrm{hpa}\left({ }^{\circ} \mathrm{C}\right)$, and $\mathbf{d}$ anomalous downwelling longwave radiation $\left(\mathrm{W} \mathrm{m}^{-2}\right)$

downwelling longwave radiation anomalies are present over most of the Arctic, with the exception of the Greenland Sea (Fig. 7c, d).

The circulation and IVT patterns of node 17 resemble those of node 18, though the low pressure system is shifted north centering on the Central Arctic (Fig. 3). Days attributed to node 17 show the greatest melt onset in the Kara (9.13\%) and Laptev (7.88\%) Seas, as well as the Central Arctic (7.86\%) (Fig. 8a) and are associated with moisture advection circling the central Arctic in a counterclockwise direction crossing the southern Arctic seas along the Siberian coast and crossing into the Chukchi and Beaufort Seas (Fig. 8b). Strong anomalous integrated vapor transport is seen across much of the Arctic Ocean (Kara: $+51.25 \mathrm{~kg} \mathrm{~m}^{-1} \mathrm{~s}^{-1}$; Laptev: $+62.54 \mathrm{~kg} \mathrm{~m}^{-1} \mathrm{~s}^{-1}$; East 
a)

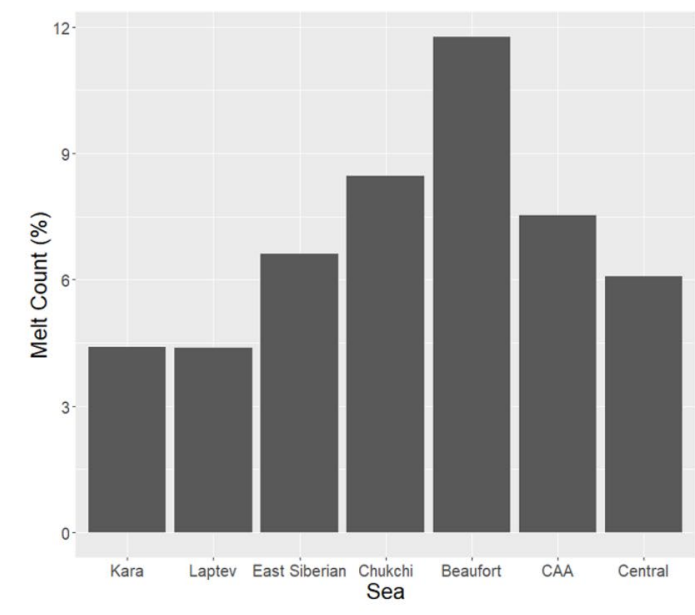

c)

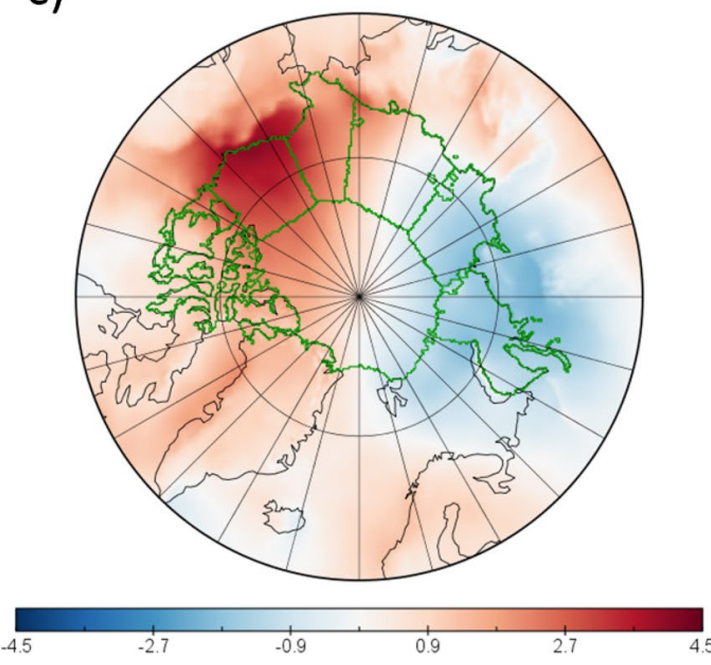

b)

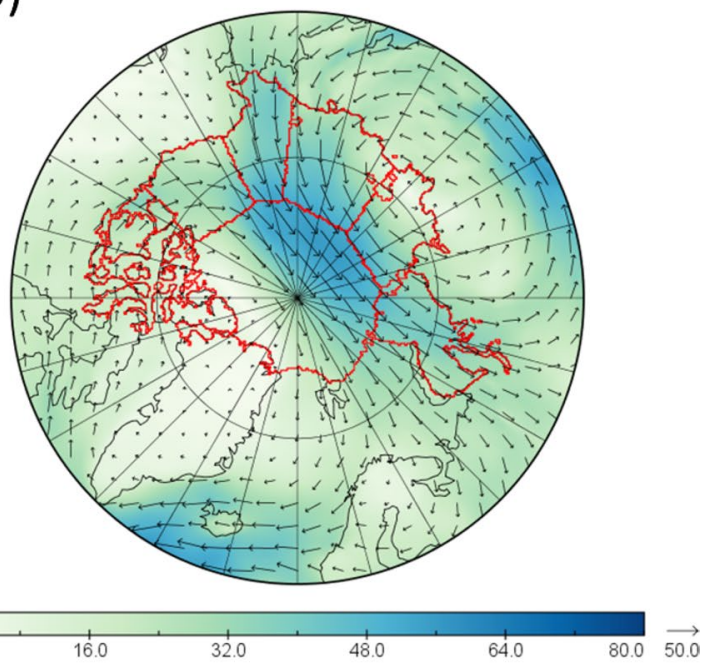

d)

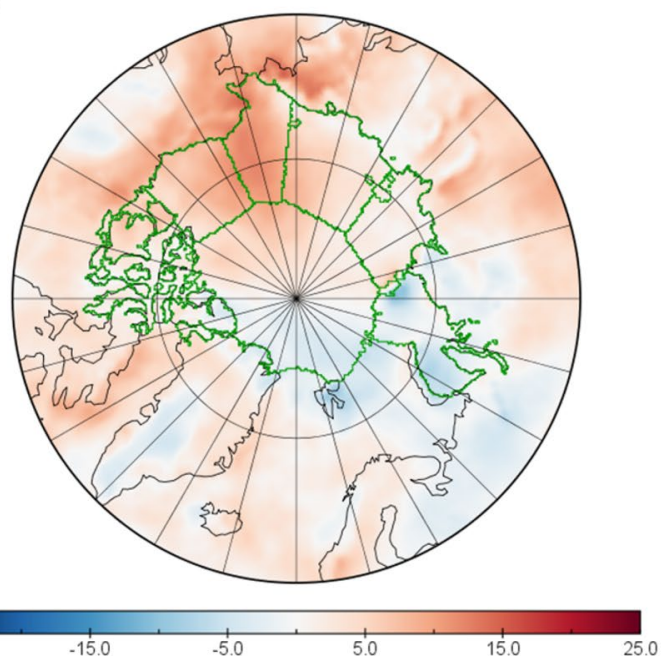

Fig. 6 Same as in Fig. 5 but for node 15

Siberian: $+65.00 \mathrm{~kg} \mathrm{~m}^{-1} \mathrm{~s}^{-1}$, Chukchi: $+50.80 \mathrm{~kg} \mathrm{~m}^{-1} \mathrm{~s}^{-1}$, Beaufort: $+54.11 \mathrm{~kg} \mathrm{~m}^{-1} \mathrm{~s}^{-1}$ ) with slightly lower values over the CAA $\left(+34.26 \mathrm{~kg} \mathrm{~m}^{-1} \mathrm{~s}^{-1}\right)$ and the central Arctic $\left(+39.94 \mathrm{~kg} \mathrm{~m}^{-1} \mathrm{~s}^{-1}\right)$. Negative temperature anomalies cover much of the Arctic Ocean with the exception of the Kara Sea $\left(+0.29^{\circ} \mathrm{C}\right)$ and CAA $\left(+0.25^{\circ} \mathrm{C}\right)$ while positive downwelling longwave radiation anomalies appear in the Kara $\left(+4.95 \mathrm{~W} \mathrm{~m}^{-2}\right)$, Laptev $\left(+1.75 \mathrm{~W} \mathrm{~m}^{-2}\right)$, Beaufort $\left(+1.86 \mathrm{~W} \mathrm{~m}^{-2}\right)$ Seas, and the CAA $\left(+1.20 \mathrm{~W} \mathrm{~m}^{-2}\right)$ (Fig. $8 \mathrm{c}$, d).

Node 10 exhibits a dipole pattern similar to node 15 , but with the centers shifted slightly in the counter-clockwise direction, resulting in an Atlantic sector high and two Pacific sector lows, one over Siberia and the other over Alaska (Fig. 3). This pattern leads to the highest rates of melt onset in the CAA $(9.13 \%)$, the central Arctic $(8.37 \%)$, and the Laptev $(7.26 \%)$ and Kara $(6.18 \%)$
Seas (Fig. 9b). Moisture is primarily advected from eastern North America over the CAA $\left(+32.40 \mathrm{~kg} \mathrm{~m}^{-1} \mathrm{~s}^{-1}\right)$ to the Central Arctic $\left(+29.07 \mathrm{~kg} \mathrm{~m}^{-1} \mathrm{~s}^{-1}\right)$ and then to the Laptev $\left(+29.62 \mathrm{~kg} \mathrm{~m}^{-1} \mathrm{~s}^{-1}\right)$ and Kara $\left(+26.15 \mathrm{~kg} \mathrm{~m}^{-1} \mathrm{~s}^{-1}\right)$ Seas. This southerly advection also causes warm air temperatures in the CAA $\left(+1.94{ }^{\circ} \mathrm{C}\right)$, the Central Arctic $\left(+0.85^{\circ} \mathrm{C}\right)$, and the Beaufort Sea $\left(+1.19^{\circ} \mathrm{C}\right)$ while negative anomalies are present in much of the Siberian sector (Chukchi: $-0.57{ }^{\circ} \mathrm{C}$; East Siberian: $-1.08{ }^{\circ} \mathrm{C}$; Laptev: $-0.94{ }^{\circ} \mathrm{C}$ ). The Kara Sea shows roughly zero temperature anomaly but there is a positive downwelling longwave radiation anomaly $\left(+1.59 \mathrm{~W} \mathrm{~m}^{-2}\right)$. In fact, all regions experience positive downwelling longwave radiation anomalies on days associated with node 10 (Laptev: $+2.12 \mathrm{~W} \mathrm{~m}^{-2}$; East Siberian: $+0.18 \mathrm{~W} \mathrm{~m}^{-2}$; Chukchi: $+2.76 \mathrm{~W} \mathrm{~m}^{-2}$; Beaufort: $+2.33 \mathrm{~W} \mathrm{~m}^{-2}$; CAA: $+3.84 \mathrm{~W} \mathrm{~m}^{-2}$; Central: $+0.64 \mathrm{~W} \mathrm{~m}^{-2}$ ) although there are areas within the East 
a)

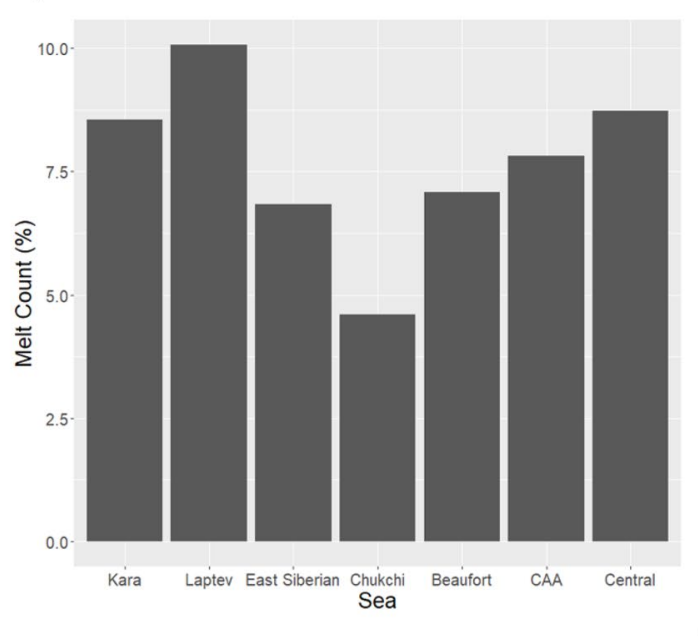

c)

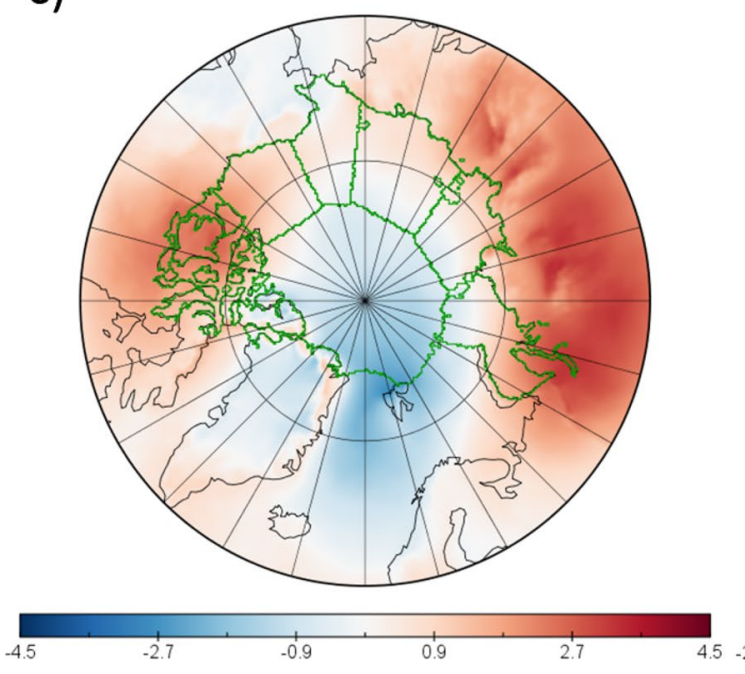

b)

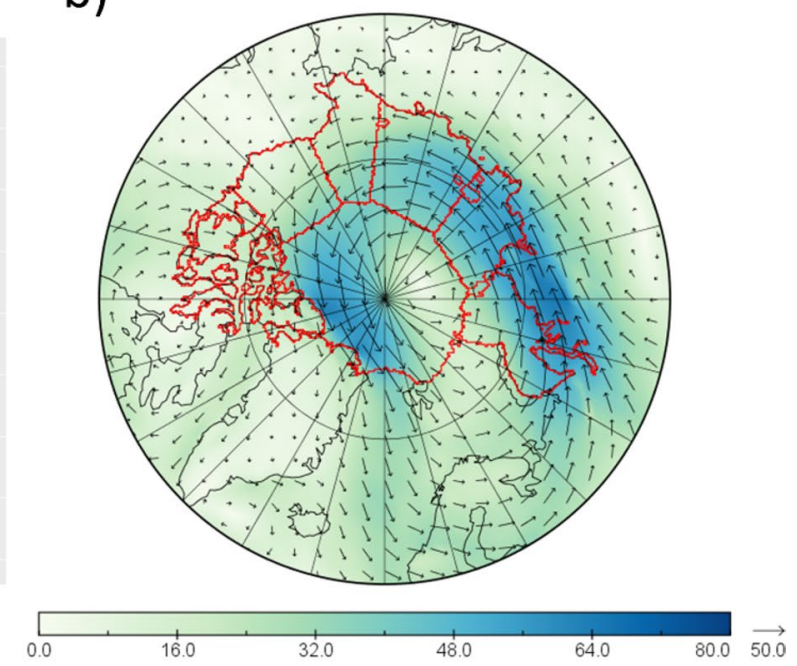

d)

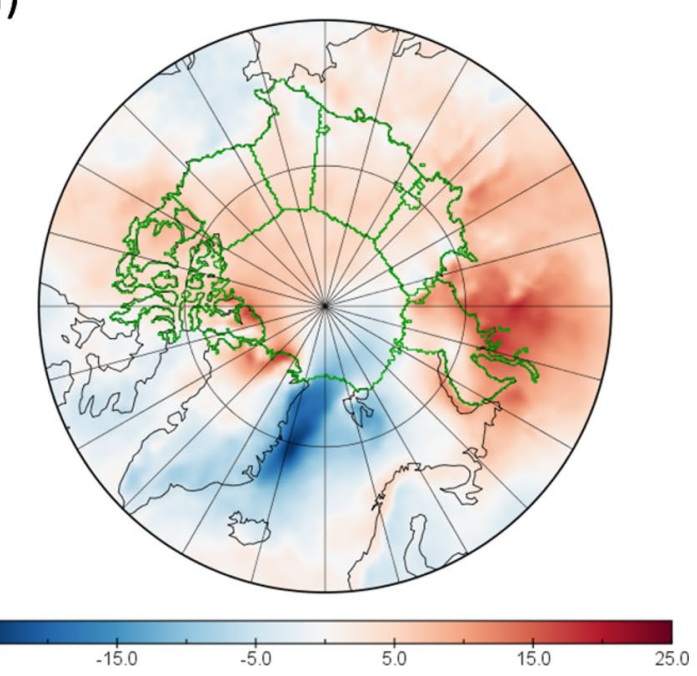

Fig. 7 Same as in Fig. 5 but for node 18

Siberian and Beaufort Seas that do experience negative anomalies (Fig. 10).

Node 3 promotes the greatest melt onset in the East Siberian Sea (9.93\%) followed by the Chukchi Sea (7.48\%) and the Central Arctic (6.27\%). This circulation pattern is defined by a high pressure system over the Beaufort Sea and Central Arctic surrounded by lower pressure (Fig. 3). This transports moisture from the North Pacific to the East Siberian (+40.43 $\left.\mathrm{kg} \mathrm{m}^{-1} \mathrm{~s}^{-1}\right)$, Laptev (+40.44 $\left.\mathrm{kg} \mathrm{m}^{-1} \mathrm{~s}^{-1}\right)$, and Kara $\left(+36.94 \mathrm{~kg} \mathrm{~m}^{-1} \mathrm{~s}^{-1}\right)$ Seas before bifurcating into a branch that leaves the Arctic towards the North Atlantic and a branch that circles the Central Arctic $\left(+29.62 \mathrm{~kg} \mathrm{~m}^{-1} \mathrm{~s}^{-1}\right)$ crossing the CAA $\left(+22.28 \mathrm{~kg} \mathrm{~m}^{-1} \mathrm{~s}^{-1}\right)$ and the Beaufort $\left(+29.97 \mathrm{~kg} \mathrm{~m}^{-1} \mathrm{~s}^{-1}\right)$ and Chukchi $\left(+21.75 \mathrm{~kg} \mathrm{~m}^{-1} \mathrm{~s}^{-1}\right)$ Seas. Anomalously high air temperature is seen across the Arctic Ocean with the exception of the CAA $\left(-0.84^{\circ} \mathrm{C}\right)$. Similarly, anomalously high downwelling longwave radiation can be seen everywhere except the CAA $\left(-1.01 \mathrm{~W} \mathrm{~m}^{-2}\right)$ and the Beaufort Sea $\left(-0.74 \mathrm{~W} \mathrm{~m}^{-2}\right)$.

In summary, melt onset in the Beaufort and Chukchi Seas is driven by southerly advection of moisture from the North Pacific and by advection from the Eurasian coast via low pressure systems over the Eurasian Arctic and a dipole low Eurasian, high North American pattern. The Laptev and East Siberian Seas are commonly influenced by moisture advection from Eurasia and Siberia and by southerly advection from the North Pacific. The East Siberian Sea is also affected by high pressure over the Beaufort Sea surrounded by lower pressure, bringing additional moisture from the North Pacific. The Laptev Sea is also affected by a Eurasian-North American dipole pattern advecting moisture from the North Pacific and Siberia. Similar to 
a)

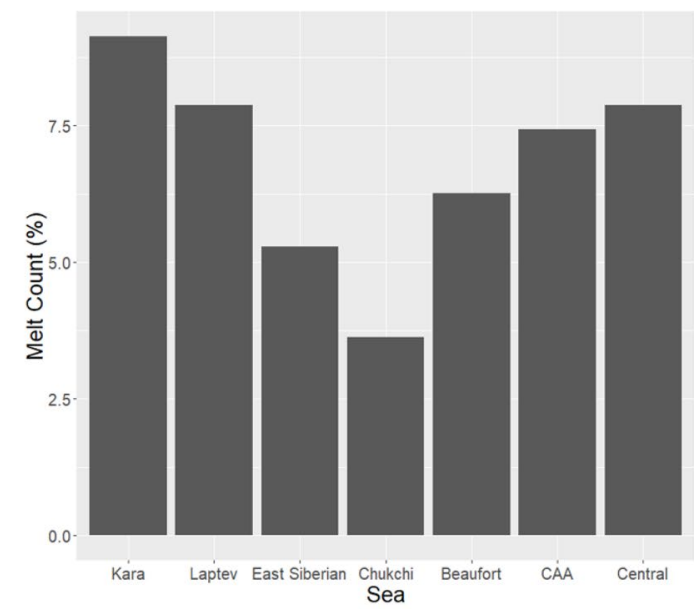

c)

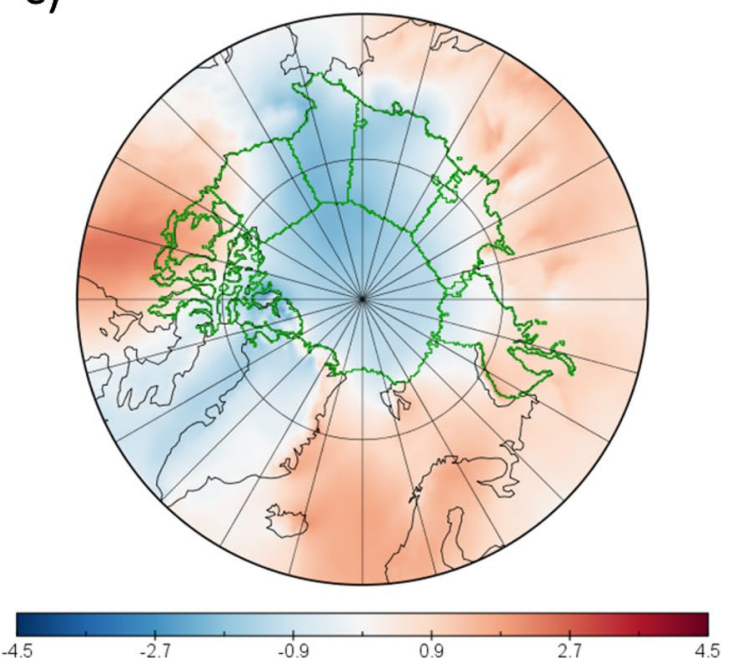

b)

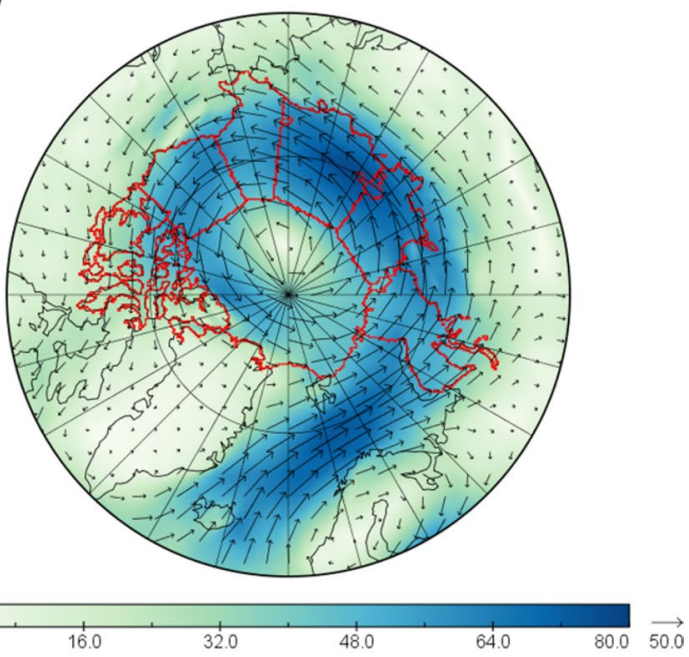

d)

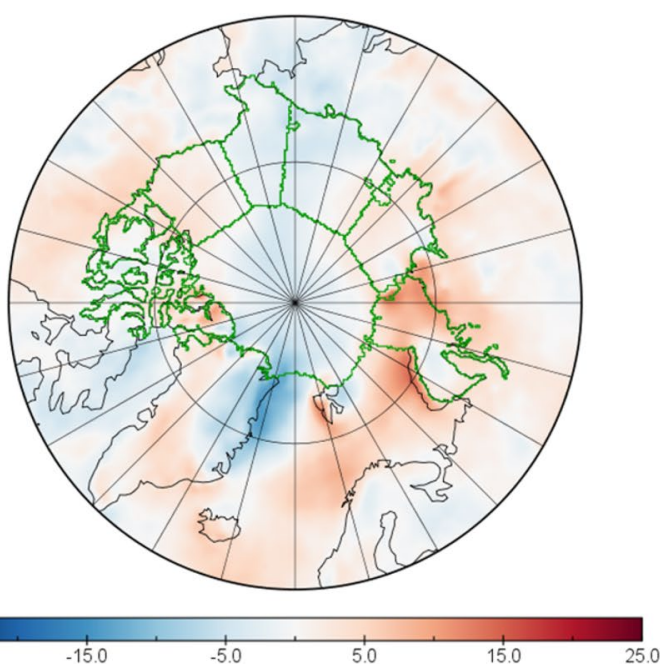

Fig. 8 Same as in Fig. 5 but for node 17

the Laptev Sea, melt onset in the Kara Sea is influenced by the central Arctic cyclonic patterns that advect moisture from the North Atlantic along the coast of Eurasia before turning north towards the central Arctic. Circulation patterns leading to melt onset in the Central Arctic and Canadian Arctic Archipelago include central Arctic cyclone patterns, a low over Siberia and the Laptev Sea accompanied by high pressure over North American and Europe, as well as a Siberian-Greenland dipole and an Atlantic-Pacific dipole pattern. Preliminary results from a separate moisture tracking analysis using particle tracking algorithms also corroborate the dominant pathways identified here (not shown). This suggests a promising path for uncovering additional insights into the moisture sources and pathways that can be of importance in predicting melt onset.

\subsection{Drivers of regional early melt onset}

In order to assess the role of the circulation patterns of the leading nodes in enabling early and late melt, we computed the number of times the circulation patterns of the four leading nodes occur in a given year during the five earliest and five latest melt onset years. This allows us to clearly see which patterns dominates during years with early melt onset and how that pattern is absent during years with late melt onset. Because melt onset only occurs once per year at each location, we limit our search to the early melt season (moisture transport after melt onset has already occurred does not contribute to the focus of this study) for all years (1979-2018). We define "early melt year" as dates before the $25 \%$ quartile of all melt onset dates for each sea (the specific choice of quartile threshold 
a)

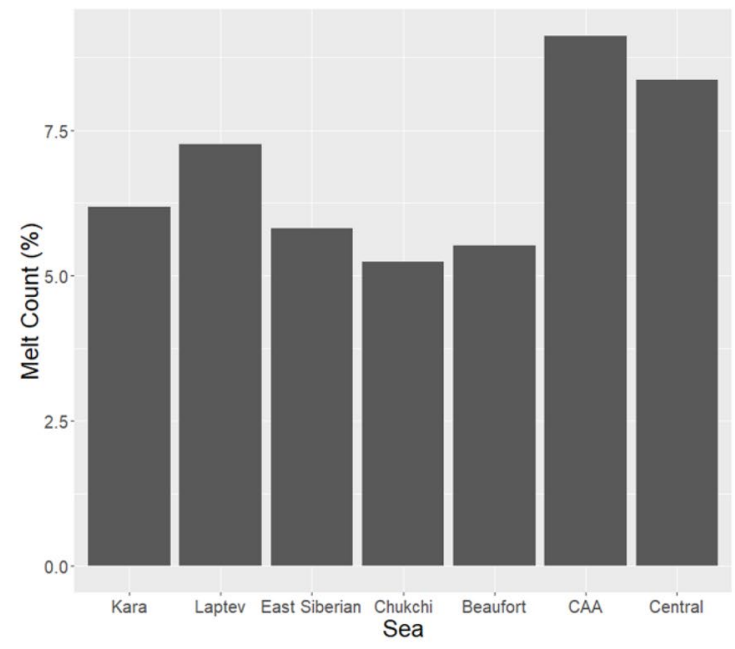

c)

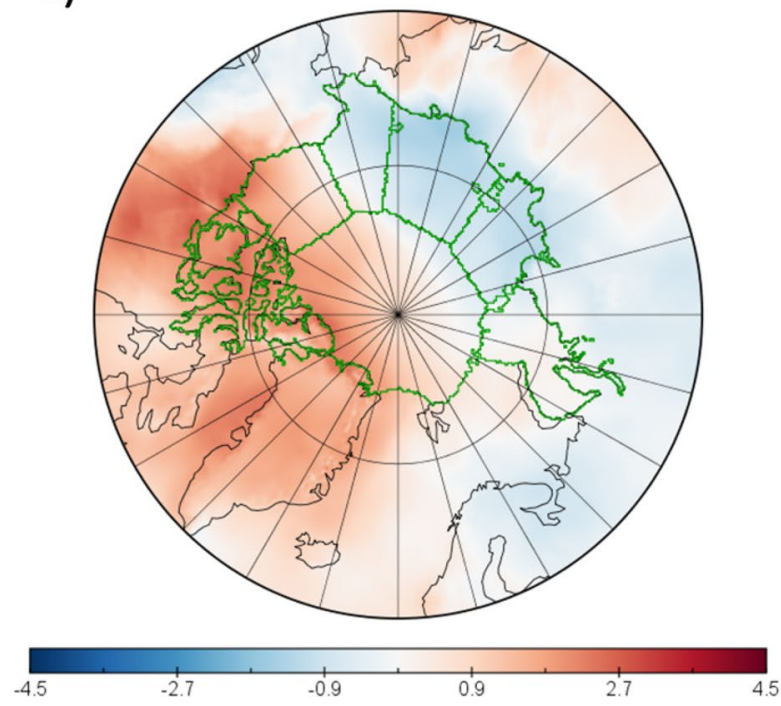

b)

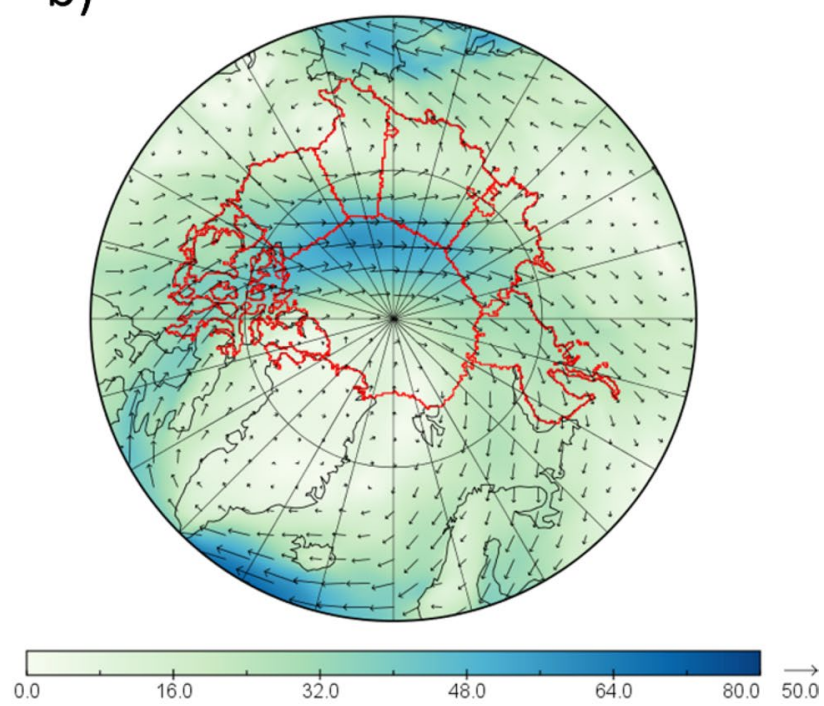

d)

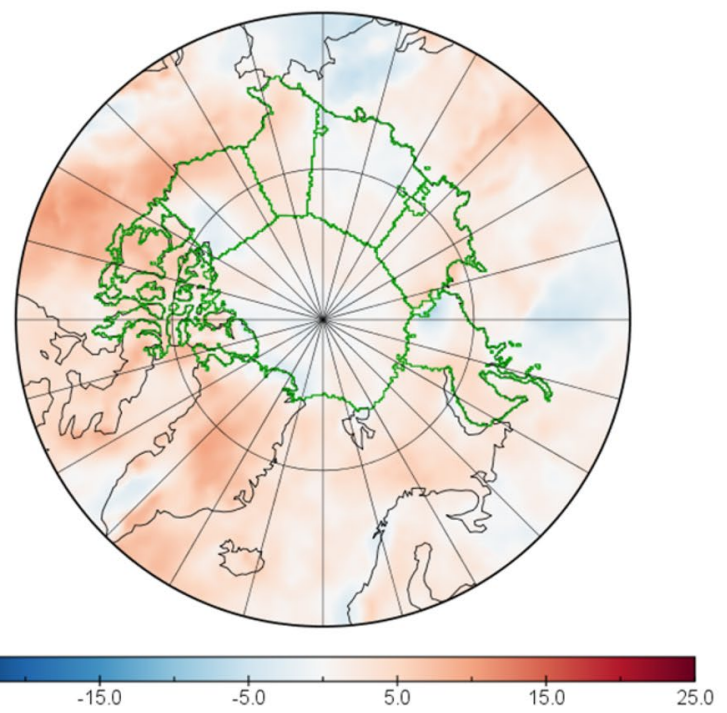

Fig. 9 Same as in Fig. 5 but for node 10

did not impact the results). The number of days associated with a given node that occur during early (late) years are shown in Table 4 (bold values show statistically significant differences at the $95 \%$ confidence level). For each sea the leading node ("1st" column) occurs more often early in the melt season during early melt years compared to late melt years, although only the Laptev, Chukchi, and Beaufort seas show statistical significance. Within the top four nodes (columns "1st" through " 4 th") there are instances where these circulation patterns occur less often in early melt years as well as instances that are not statistically significant, but the total for the top four nodes show an increase in occurrence during early years, with the exception of the Central Arctic and the Kara Sea.
Pressure patterns that are associated (statistically significant) with early melt onset fall into three general categories: (1) a low over the central Arctic with surrounding higher pressure (nodes 17 and 18); (2) a dipole low over Eurasia and high over North America or Greenland (nodes 15 and 19); and (3) a low over Siberia with highs over North America and Europe (node 13). Early melt onset in the Kara, Laptev, and East Siberian Seas are influenced by the first pattern which brings heat and moisture from the North Atlantic along the Siberian coast. The Chukchi, Beaufort, and CAA are influenced by the second pattern which primarily advects moisture from the North Pacific. The third pattern, which brings moisture from southern Siberia across the Arctic towards North America, additionally contributes to melt 
a)

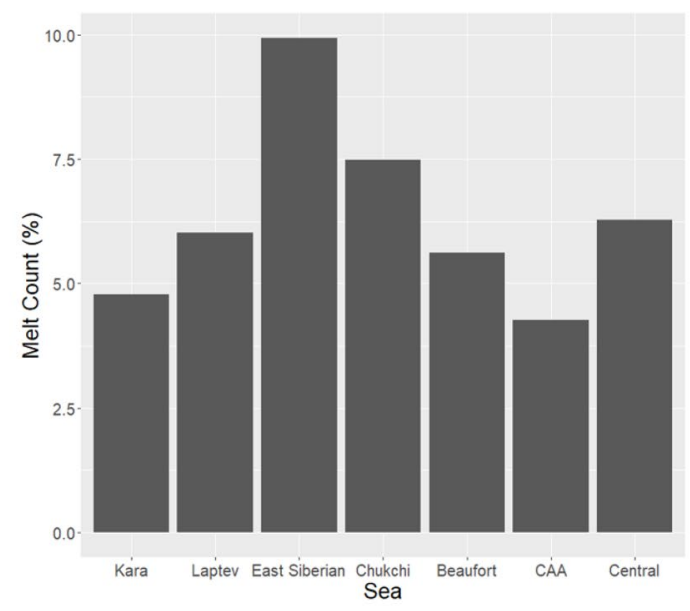

c)

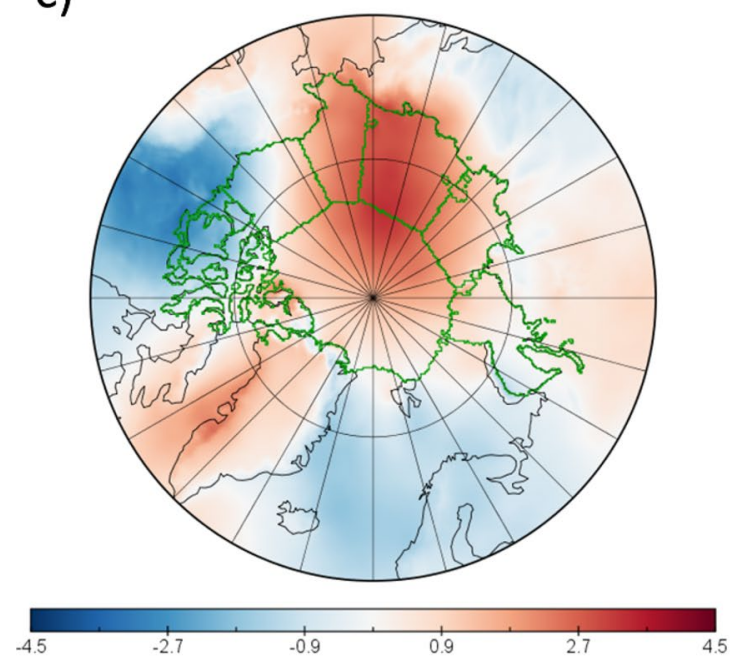

b)

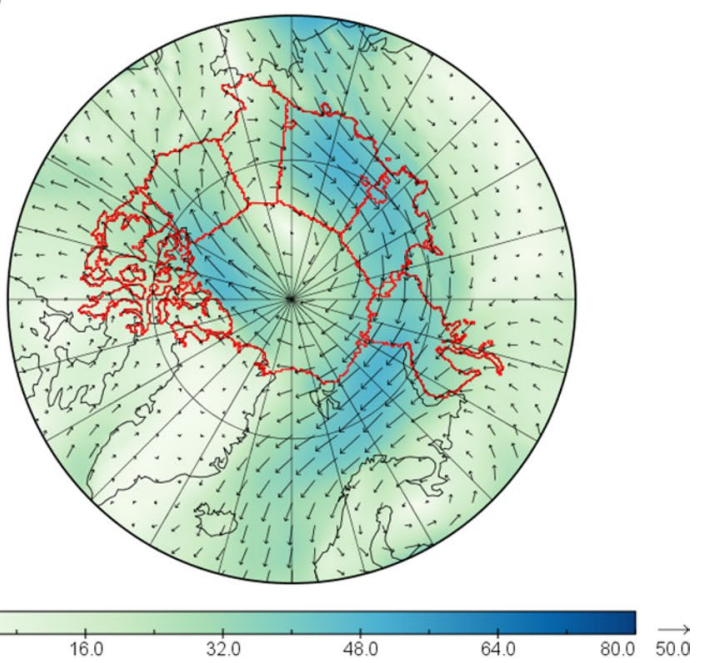

d)

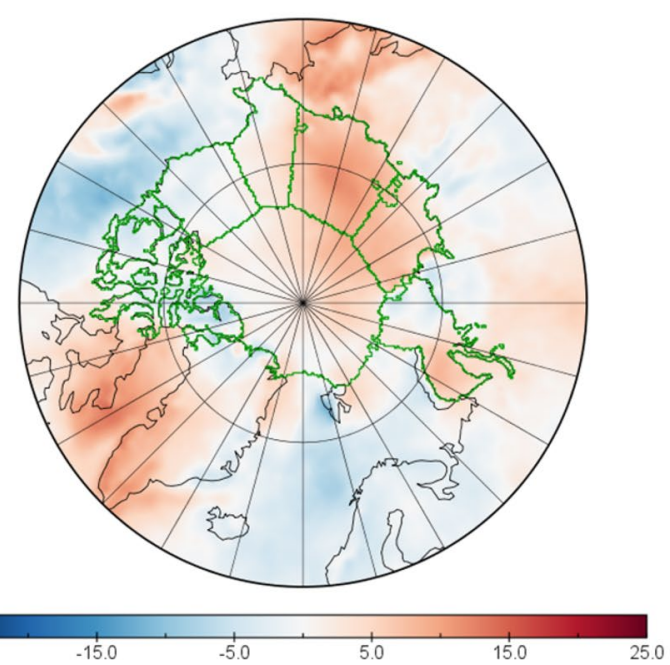

Fig. 10 Same as in Fig. 5 but for node 3

Table 4 The number of times the leading four nodes occur during five earliest (latest) melt years for each sea

\begin{tabular}{llllll}
\hline Sea & 1st & 2nd & 3rd & 4th & Total \\
\hline Kara & $8(7)$ & $\mathbf{1 2 ( 4 )}$ & $11(15)$ & $\mathbf{4 6}(\mathbf{6 4 )}$ & $77(90)$ \\
Laptev & $\mathbf{1 6 ( 7 )}$ & $\mathbf{3 3 ( 1 7 )}$ & $\mathbf{1 3 ( 3 )}$ & $\mathbf{8 ( 1 7 )}$ & $\mathbf{7 0}(\mathbf{4 4})$ \\
East Siberian & $19(11)$ & $14(18)$ & $22(21)$ & $\mathbf{2 5 ( 1 1 )}$ & $80(61)$ \\
Chukchi & $\mathbf{1 6 ( 5 )}$ & $\mathbf{1 5 ( 4 )}$ & $\mathbf{3 3 ( 8 )}$ & $5(12)$ & $\mathbf{6 9}(\mathbf{2 9})$ \\
Beaufort & $\mathbf{1 7 ( 3 )}$ & $\mathbf{1 1 ( 3 )}$ & $26(16)$ & $14(17)$ & $\mathbf{6 8}(\mathbf{3 9})$ \\
Central & $20(17)$ & $25(31)$ & $\mathbf{9 ( 3 3 )}$ & $15(14)$ & $\mathbf{6 9}(\mathbf{9 5})$ \\
CAA & $16(15)$ & $10(7)$ & $10(6)$ & $\mathbf{1 8}(\mathbf{8})$ & $\mathbf{5 4}(\mathbf{3 6})$ \\
\hline
\end{tabular}

Bold values represent statistical significance at $95 \%$ confidence level calculated using Eq. (1) onset in the Laptev, Chukchi, and Beaufort Seas. Identification of the nodes/circulation patterns that are pertinent to early melt onset lay the foundation for a potential seasonal forecast system of the timing of melt onset. For instance, statistical modeling of the likelihood that individual nodes will occur early in the melt season could be leveraged to determine regional early melt onset. The appearance of these dominant pressure patterns in the early melt season paves the way forward for future studies to connect them with wintertime atmospheric and/or oceanic states, thereby extending the lead time for sea ice forecasting.

In a similar manner, changes in early season frequency of each node from the first 15 years of data and the last 15 years of data are mapped to the master SOM (Fig. 11). Only four nodes show statistically significant (95\% confidence) changes: Nodes 3 and 19 exhibit more frequent occurrences in recent years, while nodes 5 and 11 occur 


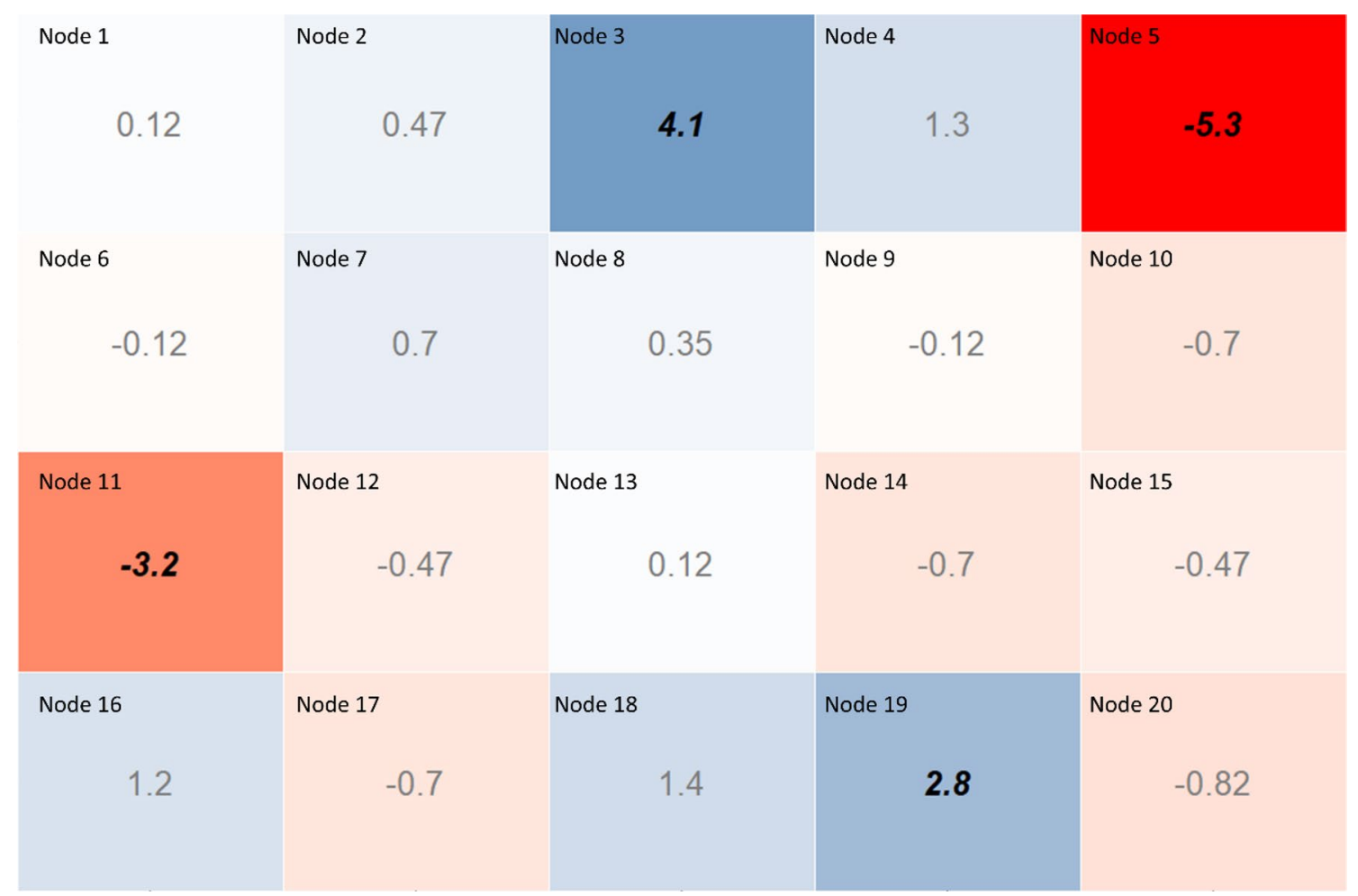

Fig. 11 Change in frequency of occurrence between years 1979-1993 and years 2004-2018. Blue tiles indicate positive change while red tiles indicate negative change. Text in bold and italics represent statistical significance at $95 \%$ confidence

less often. The high pressure center over the Beaufort and Chukchi seas accompanied by surrounding lower pressure seen in node 3 is the second leading node for melt onset in the East Siberian Sea while the Eurasian-North American dipole of node 19 is the third leading node for melt onset in the Chukchi Sea. Both of these circulation patterns advect moisture from the North Pacific into the central Arctic. While these two nodes have the greatest positive change in frequency from the first 15 years to the last 15 years, the Chukchi and East Siberian Seas exhibit relatively weak negative trends in average melt onset date (Fig. 1). The strongest negative trend in melt onset day of year is seen in the Kara Sea, which undergoes melt onset initiation influenced by moisture advection from North America (nodes 2 and 10) and from the North Atlantic (nodes 17 and 18). Nodes 2 and 18 occur more frequently in recent years while nodes 10 and 17 occur less often, but none of those changes are statistically significant at the 95\% level. Hence, while early melt season occurrence of the pressure patterns identified by SOM can explain some of the inter-annual variability of melt onset, the overall trend is driven by other factors (e.g., Arctic amplification, see Cao et al. 2017). It should be noted that in a system with so much natural variability, capturing robust statistics using only 15 years of data can be challenging, but as more years are observed going forward these statistics will become more robust.

\section{Conclusions}

This study has identified dominant patterns of synoptic atmospheric circulation that transport moisture from lower latitudes into the Arctic initiating melt onset using a selforganizing map. Specific anomalous pressure patterns that promote melt onset vary by region, but there are common pathways and potential moisture sources. In general, low pressure over Eurasia and high pressure over the central Arctic or North America often lead to the initiation of melt onset, particularly in the Laptev, East Siberian, Chukchi, and Beaufort seas. Previous work has found that this pressure pattern can be triggered by snow retreat in Eurasia (Crawford et al. 2018; Matsumura et al. 2014): As snow cover melts, the surface warms due to reduced surface albedo, amplifying stationary Rossby waves and leading to a deceleration of the polar jet (Matsumura et al. 2014). This produces negative SLP anomalies over Eurasia and positive anomalies in the central Arctic, variations of which appear on the right side of the master SOM (Fig. 3), including nodes 9 and 15 which are associated with frequent melt onset. As spring Eurasian 
snowfall has been linked to winter NAO (Ogi \& Wallace, 2007), offering a potential source of seasonal predictability for early melt onset.

Dominant pressure patterns associated with early melt onset fall into three categories: (1) a low over the central Arctic with surrounding higher pressure; (2) a dipole low over Eurasia and high over North America or Greenland; and (3) a low over Siberia with highs over North America and Europe. Years in which these patterns occur early in the season coincide with regionally averaged early melt onset in each of the seven regions addressed in this study. Three of these five dominant pressure patterns were identified as persistent nodes leading to melt onset, indicating a connection between persistence and early melt onset. There are instances in which some of the other dominant circulation patterns occur less often in early melt onset years. However, the total number of occurrences for the top nodes do show a statistically significant increase during early melt years in most cases. This shows that melt onset is not solely dependent on any one moisture pathway, but a combination of the leading pathways. Large scale patterns and their moisture transport pathways identified in this study, in combination with advanced statistical learning techniques (Hastie et al. 2009) can be useful in developing skillful forecast models of melt onset.

Supplementary Information The online version contains supplementary material available at https://doi.org/10.1007/s00382-021-05776-y.

Acknowledgements This work was supported by NOAA Grant NA15OAR4310171 and we acknowledge the contributions of the late Drew Slater. All data used is publicly available from ECMWF (https:// www.ecmwf.int/en/forecasts/datasets/reanalysis-datasets/era5) and NSIDC (https://nsidc.org/data).

Open Access This article is licensed under a Creative Commons Attribution 4.0 International License, which permits use, sharing, adaptation, distribution and reproduction in any medium or format, as long as you give appropriate credit to the original author(s) and the source, provide a link to the Creative Commons licence, and indicate if changes were made. The images or other third party material in this article are included in the article's Creative Commons licence, unless indicated otherwise in a credit line to the material. If material is not included in the article's Creative Commons licence and your intended use is not permitted by statutory regulation or exceeds the permitted use, you will need to obtain permission directly from the copyright holder. To view a copy of this licence, visit http://creativecommons.org/licenses/by/4.0/.

\section{References}

Ali SM, Pithan F (2020) Following moist intrusions into the Arctic using SHEBA observations in a Lagrangian perspective. Q J R Meteorol Soc. https://doi.org/10.1002/qj.3859

Babar B, Graversen R, Boström T (2019) Solar radiation estimation at high latitudes: assessment of the CMSAF databases, ASR and
ERA5. Sol Energy 182:397-411. https://doi.org/10.1016/j.solen er.2019.02.058

Boisvert LN, Markus T, Vihma T (2013) Moisture flux changes and trends for the entire Arctic in 2003-2011 derived from EOS Aqua data. J Geophys Res Oceans 118(10):5829-5843. https://doi.org/ 10.1002/jgrc.20414

Brodzik MJ, Knowles KW (2002) Chapter 5: EASE-Grid: A Versatile Set of Equal-Area Projections and Grids. In: Discrete Global Grids: A Web Book. National Center for Geographic Information \& Analysis. https://escholarship.org/uc/item/9492q6sm

Brodzik MJ, Billingsley B, Haran T, Raup B, Savoie MH (2012) EASE-Grid 2.0: incremental but significant improvements for earth-gridded data sets. ISPRS Int J Geo-Inf 1(1):32-45. https:// doi.org/10.3390/ijgi1010032

Brodzik MJ, Billingsley B, Haran T, Raup B, Savoie MH (2014) Correction: Brodzik, M.J., et al. EASE-Grid 2.0: Incremental but Significant Improvements for Earth-Gridded Data Sets ISPRS International Journal of Geo-Information 2012, 1, 32-45. ISPRS Int J Geo-Inf 3(3):1154-1156. https://doi.org/10.3390/ ijgi3031154

Cao Y, Liang S, Chen X, He T, Wang D, Cheng X (2017) Enhanced wintertime greenhouse effect reinforcing Arctic amplification and initial sea-ice melting. Sci Rep. https://doi.org/10.1038/ s41598-017-08545-2

Cassano JJ, Uotila P, Lynch AH, Cassano EN (2007) Predicted changes in synoptic forcing of net precipitation in large Arctic river basins during the 21st century. J Geophys Res Biogeosci. https://doi.org/ 10.1029/2006JG000332

Cassano JJ, Cassano EN, Seefeldt MW, Gutowski WJ, Glisan JM (2016) Synoptic conditions during wintertime temperature extremes in Alaska. J Geophys Res Atmos 121(7):3241-3262. https://doi.org/10.1002/2015JD024404

Cavalieri DJ, Parkinson CL (2012) Arctic sea ice variability and trends, 1979-2010. The Cryosphere; Katlenburg-Lindau 6(4):881

Crawford AD, Horvath S, Stroeve J, Balaji R, Serreze MC (2018) Modulation of sea ice melt onset and retreat in the Laptev sea by the timing of snow retreat in the West Siberian Plain. J Geophys Res Atmos 123(16):8691-8707. https://doi.org/10.1029/2018J D028697

Cronk T (2019) Climate Change Opens Door to Arctic for Competitors, DOD Official Says. U.S. DEPARTMENT OF DEFENSE. https:// www.defense.gov/Explore/News/Article/Article/2040295/clima te-change-opens-door-to-arctic-for-competitors-dod-official-says/

Ding Q, Schweiger A, L'Heureux M, Steig EJ, Battisti DS, Johnson NC, Blanchard-Wrigglesworth E, Po-Chedley S, Zhang Q, Harnos K, Bushuk M, Markle B, Baxter I (2019) Fingerprints of internal drivers of Arctic sea ice loss in observations and model simulations. Nat Geosci 12(1):28-33. https://doi.org/10.1038/ s41561-018-0256-8

Drumond A, Taboada E, Nieto R, Gimeno L, Vicente-Serrano SM, López-Moreno JI (2016) A Lagrangian analysis of the present-day sources of moisture for major ice-core sites. Earth Syst Dynam 7(3):549-558. https://doi.org/10.5194/esd-7-549-2016

Eguíluz VM, Fernández-Gracia J, Irigoien X, Duarte CM (2016) A quantitative assessment of Arctic shipping in 2010-2014. Sci Rep 6(1):30682. https://doi.org/10.1038/srep30682

Ellis B, Brigham L (2009) Arctic Marine Shipping Assessment 2009 Report. https://oaarchive.arctic-council.org/handle/11374/54

Copernicus Climate Change Service (C3S) (2017). (n.d.). ERA5: Fifth generation of ECMWF atmospheric reanalyses of the global climate. Copernicus Climate Change Service Climate Data Store (CDS). Retrieved January 6, 2020, from https://cds.climate.coper nicus.eu/cdsapp\#!/home

Garamone J (2019) Changing Environment Means Changing Arctic Strategy. U.S. DEPARTMENT OF DEFENSE. https://www.defen 
se.gov/Explore/News/Article/Article/1865978/changing-envir onment-means-changing-arctic-strategy/

Graham RM, Cohen L, Ritzhaupt N, Segger B, Graversen RG, Rinke A, Walden VP, Granskog MA, Hudson SR (2019) Evaluation of six atmospheric reanalyses over Arctic sea ice from winter to early summer. J Clim. https://doi.org/10.1175/JCLI-D-18-0643.1

Hansen CØ, Grønsedt P, Graversen CL, Hendriksen C (2016) Arctic Shipping: Commercial Opportunities and Challenges. CBS Maritime. https://research.cbs.dk/en/publications/arctic-shipp ing-commercial-opportunities-and-challenges

Hastie T, Tibshirani R, Friedman J (2009) The sction, 2nd edn. Springer Science \& Business Media, New York

Higgins ME, Cassano JJ (2009) Impacts of reduced sea ice on winter Arctic atmospheric circulation, precipitation, and temperature. $\mathbf{J}$ Geophys Res Atmos. https://doi.org/10.1029/2009JD011884

Horton DE, Johnson NC, Singh D, Swain DL, Rajaratnam B, Diffenbaugh NS (2015) Contribution of changes in atmospheric circulation patterns to extreme temperature trends. Nature 522(7557):465-469. https://doi.org/10.1038/nature 14550

Huang Y, Chou G, Xie Y, Soulard N (2019) Radiative control of the interannual variability of Arctic Sea Ice. Geophys Res Lett 46(16):9899-9908. https://doi.org/10.1029/2019GL084204

Johnson NC, Feldstein SB, Tremblay B (2008) The continuum of northern hemisphere teleconnection patterns and a description of the NAO shift with the use of self-organizing maps. J Clim 21(23):6354-6371. https://doi.org/10.1175/2008JCLI2380.1

Kapsch M-L, Skific N, Graversen RG, Tjernström M, Francis JA (2019) Summers with low Arctic sea ice linked to persistence of spring atmospheric circulation patterns. Clim Dyn 52(3):2497-2512. https://doi.org/10.1007/s00382-018-4279-z

Kohonen T (1990) The self-organizing map. Proc IEEE 78(9):14641480. https://doi.org/10.1109/5.58325

Li F, Wang H, Gao Y (2015) Extratropical Ocean warming and winter arctic sea ice cover since the 1990s. J Clim 28(14):5510-5522. https://doi.org/10.1175/JCLI-D-14-00629.1

Markus T, Stroeve JC, Miller J (2009) Recent changes in Arctic sea ice melt onset, freezeup, and melt season length. J Geophys Res Oceans. https://doi.org/10.1029/2009JC005436

Matsumura S, Zhang X, Yamazaki K (2014) Summer Arctic atmospheric circulation response to spring Eurasian snow cover and its possible linkage to accelerated sea ice decrease. J Clim 27(17):6551-6558. https://doi.org/10.1175/JCLI-D-13-00549.1

Mioduszewski JR, Rennermalm AK, Hammann A, Tedesco M, Noble EU, Stroeve JC, Mote TL (2016) Atmospheric drivers of Greenland surface melt revealed by self-organizing maps. J Geophys Res Atmos 121(10):5095-5114. https://doi.org/10.1002/2015J D024550

Mohr M (2004) Problems with the mean-sea-level pressure field over the Western United States. Mon Weather Rev 132(8):1952-1965

Mortin J, Svensson G, Graversen RG, Kapsch M-L, Stroeve JC, Boisvert LN (2016) Melt onset over Arctic sea ice controlled by atmospheric moisture transport. Geophys Res Lett 43(12):6636-6642. https://doi.org/10.1002/2016GL069330

Ogi M, Wallace JM (2007) Summer minimum Arctic sea ice extent and the associated summer atmospheric circulation. Geophys Res Letts. https://doi.org/10.1029/2007GL029897

Onarheim IH, Eldevik T, Smedsrud LH, Stroeve JC (2018) Seasonal and regional manifestation of Arctic Sea ice loss. J Clim 31(12):4917-4932. https://doi.org/10.1175/JCLI-D-17-0427.1

Overland JE, Wang M (2005) The third Arctic climate pattern: 1930s and early 2000s. Geophys Res Lett. https://doi.org/10.1029/2005G L024254

Perovich DK, Polashenski C (2012) Albedo evolution of seasonal Arctic sea ice. Geophys Res Lett. https://doi.org/10.1029/2012G L051432
Perovich DK, Nghiem SV, Markus T, Schweiger A (2007) Seasonal evolution and interannual variability of the local solar energy absorbed by the Arctic sea ice-ocean system. J Geophys Res Oceans. https://doi.org/10.1029/2006JC003558

Persson POG (2012) Onset and end of the summer melt season over sea ice: thermal structure and surface energy perspective from SHEBA. Clim Dyn 39(6):1349-1371. https://doi.org/10.1007/ s00382-011-1196-9

Persson POG, Shupe MD, Perovich D, Solomon A (2017) Linking atmospheric synoptic transport, cloud phase, surface energy fluxes, and sea-ice growth: observations of midwinter SHEBA conditions. Clim Dyn 49(4):1341-1364. https://doi.org/10.1007/ s00382-016-3383-1

R Core Team (2019) R: a language and environment for statistical computing. R Foundation for Statistical Computing. https://www.Rproject.org/

Schröder D, Feltham DL, Flocco D, Tsamados M (2014) September Arctic sea-ice minimum predicted by spring melt-pond fraction. Nat Clim Chang 4(5):353-357. https://doi.org/10.1038/nclim ate 2203

Serreze MC, Stroeve J, Barrett AP, Boisvert LN (2016) Summer atmospheric circulation anomalies over the Arctic Ocean and their influences on September sea ice extent: a cautionary tale. J Geophys Res Atmos 121(19):11463-11485. https://doi.org/10.1002/2016J D025161

Skific N, Francis J (2012) Self-organizing maps: a powerful tool for the atmospheric sciences. Appl Self-Organ Maps. https://doi.org/ $10.5772 / 54299$

Skific N, Francis JA, Cassano JJ (2009) Attribution of projected changes in atmospheric moisture transport in the arctic: a selforganizing map perspective. J Clim 22(15):4135-4153. https:// doi.org/10.1175/2009JCLI2645.1

Smith A, Jahn A (2019) Definition differences and internal variability affect the simulated Arctic sea ice melt season. Cryosphere 13(1):1-20. https://doi.org/10.5194/tc-13-1-2019

Smith LC, Stephenson SR (2013) New Trans-Arctic shipping routes navigable by midcentury. Proc Natl Acad Sci 110(13):E1191E1195. https://doi.org/10.1073/pnas.1214212110

Stohl A (2006) Characteristics of atmospheric transport into the Arctic troposphere. J Geophys Res Atmos. https://doi.org/10.1029/2005J D006888

Stroeve J, Notz D (2018) Changing state of Arctic sea ice across all seasons. Environ Res Lett 13(10):103001. https://doi.org/10.1088/ 1748-9326/aade56

Stroeve JC, Markus T, Boisvert L, Miller J, Barrett A (2014) Changes in Arctic melt season and implications for sea ice loss. Geophys Res Lett 41(4):1216-1225. https://doi.org/10.1002/2013GL0589 51

Vázquez M, Nieto R, Drumond A, Gimeno L (2016) Moisture transport into the Arctic: source-receptor relationships and the roles of atmospheric circulation and evaporation. J Geophys Res Atmos 121(22):13493-13509. https://doi.org/10.1002/2016JD025400

Vesanto J, Alhoniemi E (2000) Clustering of the self-organizing map. IEEE Trans Neural Netw 11(3):586-600. https://doi.org/10.1109/ 72.846731

Wallace JM, Hobbs PV (2006) Atmospheric science: an introdcutory story. Elsevier. https://doi.org/10.1016/C2009-0-00034-8

Wehrens R, Buydens LMC (2007) Self- and SUPER-organizing Maps in R: the kohonen Package. J Stat Softw 21(1):1-19. https://doi. org/10.18637/jss.v021.i05

Wehrens R, Kruisselbrink J (2018) Flexible self-organizing maps in kohonen 30. J Stat Softw 87(1):1-18. https://doi.org/10.18637/ jss.v087.i07

Wernli H, Papritz L (2018) Role of polar anticyclones and mid-latitude cyclones for Arctic summertime sea-ice melting. Nat Geosci 11(2):108-113. https://doi.org/10.1038/s41561-017-0041-0 
Yu L, Zhong S, Zhou M, Lenschow DH, Sun B (2018) Revisiting the linkages between the variability of atmospheric circulations and Arctic melt-season sea ice cover at multiple time scales. J Clim 32(5):1461-1482. https://doi.org/10.1175/JCLI-D-18-0301.1

Publisher's Note Springer Nature remains neutral with regard to jurisdictional claims in published maps and institutional affiliations. 